\title{
Covid-19 Consequences: A Review on the linkages between 2019 Novel Coronavirus (2019-nCoV) Pandemic, Sustainable Development Goals (SDGs) and Air Contaminants $\left(\mathrm{NO}_{2}, \mathrm{O}_{3}, \mathrm{PM} 10, \mathrm{PM} 2.5 \& \mathrm{CO}_{2}\right)$
}

Nurhafizul Abu Seri, Anisah Jessica Lee

To Link this Article: http://dx.doi.org/10.6007/IJARBSS/v11-i1/8333

DOI:10.6007/IJARBSS/v11-i1/8333

Received: 25 November 2020, Revised: 19 December 2020, Accepted: 04 January 2021

Published Online: 18 January 2021

In-Text Citation: (Seri \& Lee, 2021)

To Cite this Article: Seri, N. A., \& Lee, A. J. (2021). Covid-19 Consequences: A Review on the linkages between 2019 Novel Coronavirus (2019-nCoV) Pandemic, Sustainable Development Goals (SDGs) and Air Contaminants (NO2, O3, PM 10, PM 2.5 \& CO2). International Journal of Academic Research in Business and Social Sciences, 11(1), 180-212.

\section{Copyright: (c) 2021 The Author(s)}

Published by Human Resource Management Academic Research Society (www.hrmars.com)

This article is published under the Creative Commons Attribution (CC BY 4.0) license. Anyone may reproduce, distribute, translate and create derivative works of this article (for both commercial and non-commercial purposes), subject to full attribution to the original publication and authors. The full terms of this license may be seen at: http://creativecommons.org/licences/by/4.0/legalcode

Vol. 11, No. 1, 2021, Pg. 180 - 212 


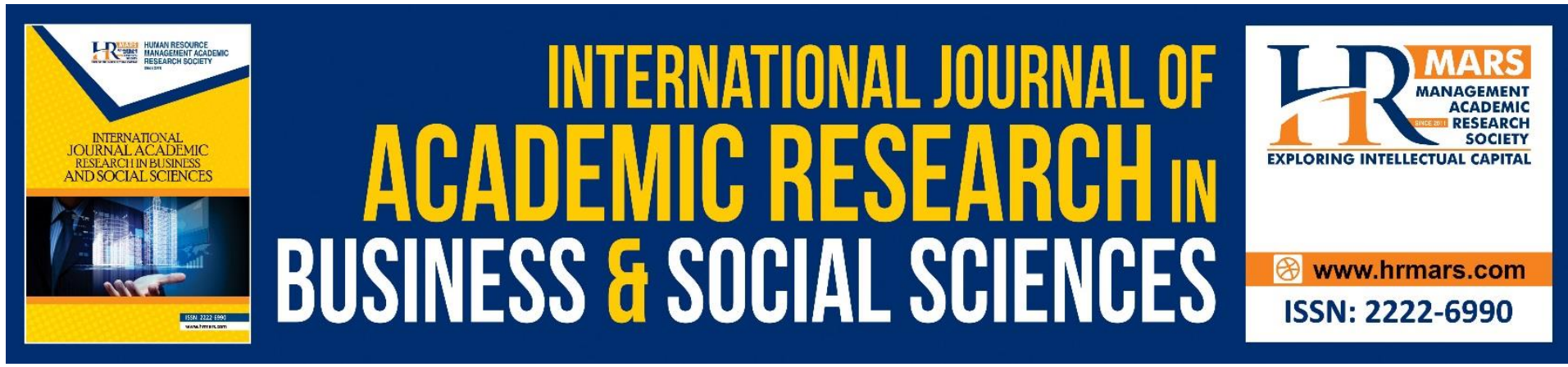

\title{
Covid-19 Consequences: A Review on the linkages between 2019 Novel Coronavirus (2019- nCoV) Pandemic, Sustainable Development Goals (SDGs) and Air Contaminants $\left(\mathrm{NO}_{2}, \mathrm{O}_{3}, \mathrm{PM} 10, \mathrm{PM}\right.$ $\left.2.5 \& \mathrm{CO}_{2}\right)$
}

\author{
Nurhafizul Abu Seri ${ }^{1}$, Anisah Jessica Lee ${ }^{2}$ \\ ${ }^{1}$ Geoinformatic Unit, Geography Section, School of Humanities, Universiti Sains Malaysia, \\ 11800 USM, Penang, Malaysia, ${ }^{2}$ Associate Professor, Geoinformatic Unit, Geography \\ Section, School of Humanities, Universiti Sains Malaysia, 11800 USM, Penang, Malaysia. \\ Email: nurhafizul.abuseri97@gmail.com, anisah@usm.my
}

\begin{abstract}
Covid-19 is one of the deadliest viruses ever seen in human civilization to date. This paper discusses the relationship between the novel coronavirus 2019 (2019-nCoV) pandemic and air contaminants namely nitrogen dioxide $\left(\mathrm{NO}_{2}\right)$, ozone $\left(\mathrm{O}_{3}\right)$, particulate matter 10 (PM 10), particulate matter 2.5 (PM 2.5) and carbon dioxide $\left(\mathrm{CO}_{2}\right)$, and human health. Exposure to the five contaminants will further intensify the spread of the disease and may contribute to mortality. At the same time, however, Covid-19 has a beneficial effect in minimizing the release of all five contaminants into the air. Second, this paper also analyses the relationship between the impact of Covid-19 on the possible success of the Sustainable Development Goals (SDGs). Ten SDGs most affected by this pandemic are No Poverty, Zero Hunger, Good Health and Well-being, Quality Education, Gender Equality, Clean Water and Sanitation, Affordable and Clean Energy, Decent Work and Economic Growth, Sustainable Cities and Communities and Peace, Justice and Strong Institutions. Some of the SDGs are negatively impressed, but there are still those that are positively impressed. Emergency responses and strategies, and eventually policies should prioritize the 10 SDGs while addressing the defining elements significantly related to Covid-19 outbreak. This pandemic has taught us an enormous lesson to be vigilant and to set our priorities right for the sake of mankind, and in achieving sustainability.
\end{abstract}

Keywords: Air Contaminants, Covid-19, Carbon Dioxide, Air Particulate Matter, PM10, PM2.5, Mortality, Sustainable Development Goals (SDGs), Human Health

Introduction: Covid-19 Global Pandemic

A new coronavirus outbreak, the severe acute respiratory syndrome coronavirus 2 (SARSCoV-2) (Covid-19) causing a rare pneumonia occurred in Wuhan city, Hubei province, China, on 31 December 2019 (Huang et al. 2020; Li, 2020; Wu et al. 2020a; Zhu et al. 2020). Covid- 
19 spread by infecting millions of people not only in China but across the world (Simonovich et al. 2020) except Antarctica (Rodríguez-Morales et al. 2020) prompting the WHO to announce a global Covid-19 pandemic on 11 March 2020. A total of 66 million confirmed cases of COVID-19 and approximately 1529746 deaths were recorded from 31 December 2019 to 06 December 2020. Cases reported on the African continent are (2,250,092 cases); Asia $(16,197,473$ cases); America $(28,552,974$ cases); Europe $(19,315,528$ cases); Oceania $(52,670$ cases); and the rest are 696 cases of foreign transmission in Japan (European Center for Disease Prevention and Control, 2020a) (Figure 1).

Coronaviruses are RNA-enveloped viruses that cause infectious, enteric, hepatic, and neurological diseases and may spread to humans, other mammals, and birds (Weiss and Leibowitz, 2011). In addition to Covid-19, there are two other coronaviruses (CoVs) that once posed a major global health emergency, namely acute coronavirus respiratory syndrome (SARS-CoV), which occurred in 2002 (Wu et al. 2020a). SARS-CoV also originates in South East China especially in Guangdong Province (Wu et al. 2020b). Meanwhile the Middle East respiratory coronavirus syndrome (MERS-CoV) occurred in 2012. MERS-CoV emerged in Saudi Arabia for the first time (Adela et al. 2020). SARS-CoV has spread to 37 countries, while MERSCoV has spread to 27 countries (Wu et al. 2020a). The case fatality rate (CFR) of SARS was 9.6 $\%$ (Donnelly et al. 2003) and the MERS $34.5 \%$ (Majumder et al. 2014). As of 6 December 2020, the outbreak of Covid-19 has been confirmed in more than 220 nations, regions, or territories (World Health Organization, 2020a).
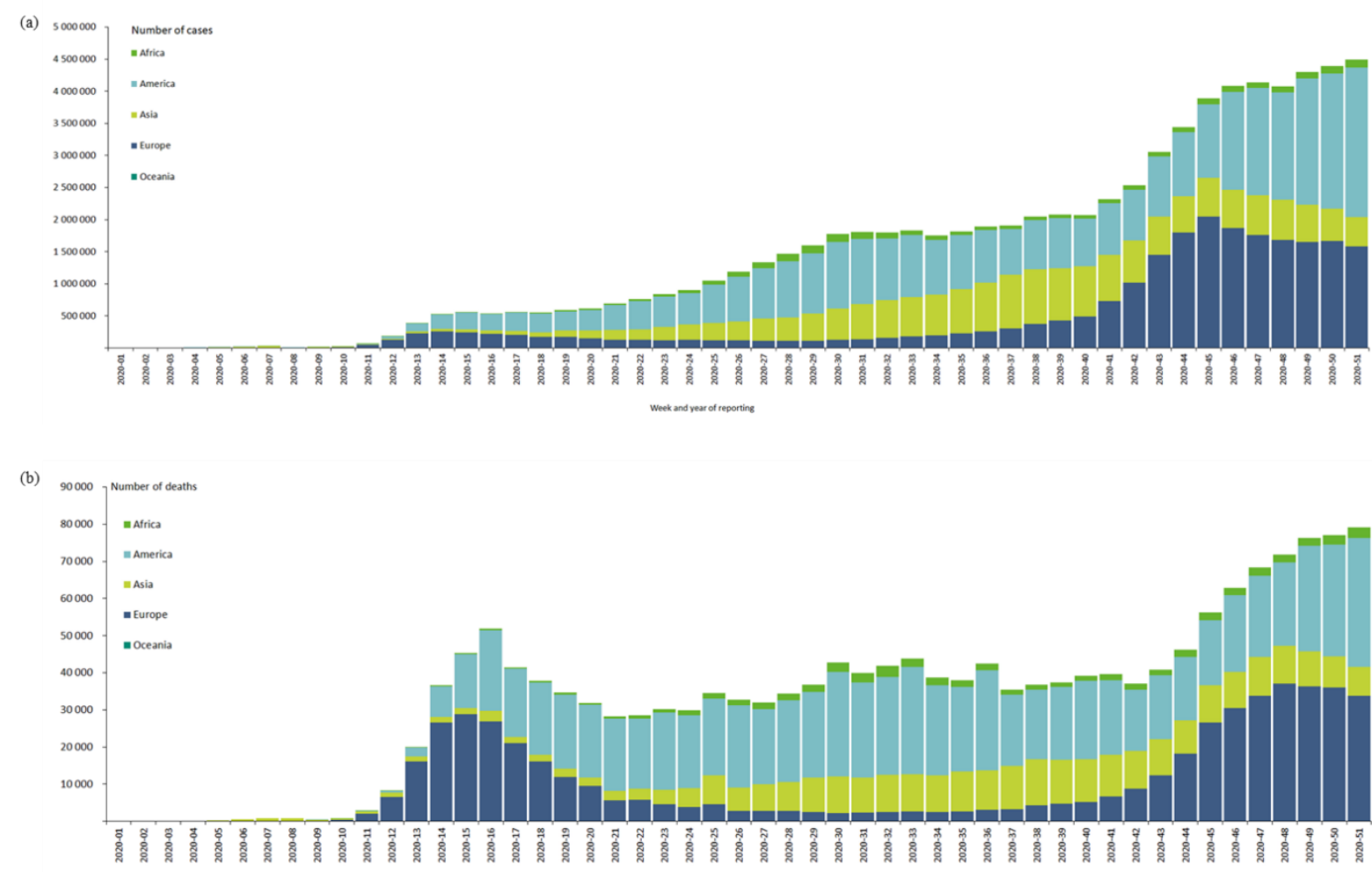

Figure 1. (a) Distribution of COVID-19 cases by continents, as of week 51 2020; (b) Distribution of COVID-19 deaths by continents, as of week 512020 (Source: European Centre for Disease Prevention and Control, 2020a) 
Covid-19 occurs due to severe acute respiratory syndrome coronavirus 2 or known as SARSCoV-2 which is usually characterized by respiratory tract symptoms and fever (Guan et al. 2020). There are 2-10 percent of Covid-19 patients experiencing gastrointestinal symptoms (diarrhea, abdominal pain, and vomiting) based on preliminary reports from Wuhan (Wang et al. 2020a; Chen et al. 2020a). Covid-19 transmission can occur through respiratory droplets and the incidence of respiratory symptoms is lower. Fever, cough, and shortness of breath are also part of the occurrence of lower respiratory symptoms. Infections that occur within 5 days of exposure (Gandhi et al. 2020a). Meanwhile, according to Wu et al. (2020b), the symptoms of Covid-19 infection include fever, dry cough, and fatigue.

Again, Wu et al. (2020b) suggests that different mechanisms could be involved, including breathing (cough, shortness of breath, sore throat, rhinorrhea, hemoptysis, and chest pain), gastrointestinal (diarrhoea, nausea and vomiting), musculoskeletal (muscle pain) and neurology (headache or confusion). He also stated that the most common signs and symptoms are fever (83-98 \%), cough (76-82 \%) and shortness of breath (31-55\%). About 97.5 $\%$ of patients experience symptoms predominantly within 11-12 days of infection, based on research (Gandhi et al., 2020b; Li et al., 2020a). Fecal-oral transmission of this virus (Hindson 2020; Gu et al., 2020; Yeo et al., 2020) can also occur, with symptoms ranging from very mild to very extreme (Gandhi et al., 2020b). It has also been found that there are people who are infected but are asymptomatic (Ong et al., 2020).

Epidemiologically, Covid-19 is associated with a wholesale market for seafood and wet animals in Wuhan City, Hubei Province, China (Chen et al. 2020a; Li et al. 2020a; Wu et al. 2020d) and spreads the virus through the transmission of illegally traded wild animals to that wholesale market (Chen et al., 2020a). Forty-one cases of novel coronavirus-infected pneumonia (NCIP) that were first reported have a history of Huanan Seafood Wholesale Market exposure (Huang et al., 2020). Covid-19 was found in a sample of a patient's bronchoalveolar lavage fluid in Wuhan and was later confirmed to be the cause of the incidence of NCIP (Zhu et al., 2020). On 31 December 2019, local health authorities in China released an epidemiological alert and ordered the closure of the wholesale market on 1 January 2020. The market closure order was carried out as $66 \%$ of its workers were listed as contaminated with the Covid-19 virus (Wu et al., 2020b).

A full travel ban order for residents around Wuhan, which was implemented on 23 January 2020 , is still unable to curb the spread of the virus. As a result of the rapid spread of Covid19, the World Health Organization (WHO) declared a global emergency on 30 January 2020. In a comparatively short period of less than 3 months, Covid-19 has spread across the world and has been declared a global epidemic (World Health Organization, 2020b). It is mainly guided by the movement of infected people through the air (Khanh et al., 2020). In fact, this is not the first time a global emergency has been declared and in the past many global emergencies have occurred, such as the outbreak of Ebola in the Democratic Republic of Congo and the Zika virus (Liu et al., 2020a). Apart from China, several other countries have also started to introduce border closures to discourage foreign visitors from transmitting the virus (Ghosh et al., 2020). In addition to the lockdown, social distances, wearing protective masks, enhanced hygiene concepts and temporary closures are among the steps taken in most countries around the world (Jung et al., 2020).

It is well known that to curb the spread of the Covid-19 outbreak, most countries are introducing a lockdown that causes several industries or manufacturing operations to be shut down globally. The transport and tourism industries are among the sectors most seriously impacted by countries' actions in the implementation of lockdowns. China is the first country 
to fully stop commercial activities, restrict domestic and foreign travel and introduce a detention regime for its citizens (Huang et al., 2020). Travel bans and lockdowns were later enforced worldwide (Narayan et al., 2020). Changes in human activity caused by the COVID19 pandemic (Liu et al., 2020b) have affected carbon dioxide $\left(\mathrm{CO}_{2}\right)$ emissions where previously, there was emission increase by about $1 \%$ each year in the decades before the COVID-19 pandemic hit in 2020 (Peters et al., 2020).

Generally, this paper attempts to discuss the linkages between the novel 2019 coronavirus (2019-nCoV) pandemic with air contaminants such as Nitrogen dioxide $\left(\mathrm{NO}_{2}\right)$, Ozone $\left(\mathrm{O}_{3}\right)$, Particulate Matter 10 (PM 10), Particulate Matter 2.5 (PM 2.5) and $\mathrm{CO}_{2}$, and the relationship between Covid-19 consequences with Sustainable Development Goals (SDGs) achievement. The objectives of this paper are:

- to identify how Covid-19 affected humans, and the environment globally,

- to identify the effect of air contaminants namely $\mathrm{NO}_{2}, \mathrm{O}_{3}, \mathrm{PM} 10, \mathrm{PM} 2.5$ and $\mathrm{CO}_{2}$ on the Covid-19 pandemic crisis, and

- to analyze the relationship between Covid-19 and the ongoing Sustainable Development Goals (SDGs) efforts.

The objectives are formed based on the notion that:

(1) Covid-19 has high severity (negative) effect on the human health particularly amongst the elderly regardless of whether they have underlying diseases or health problems, and those with health problems regardless of age groups.

(2) Covid-19 has an immediate positive effect on the environment where pollution levels are concerned.

(3) All air contaminants addressed $\left(\mathrm{NO}_{2}, \mathrm{O}_{3}, \mathrm{PM} 10, \mathrm{PM} 2.5\right.$ and $\left.\mathrm{CO}_{2}\right)$ will have an increased impact on Covid-19 pandemic crisis.

(4) Covid-19 has delayed some SDGs efforts while intensifying some SDGs, in particular those that are directly related to the physical environment although only temporary.

\section{The Linkages between 2019 Novel Coronavirus (2019-nCoV) Pandemic and Air Contaminants $\left(\mathrm{NO}_{2}, \mathrm{O}_{3}, \mathrm{PM} \mathrm{10}, \mathrm{PM} 2.5 \& \mathrm{CO}_{2}\right)$}

In 1750, the atmospheric $\mathrm{CO}_{2}$ concentration rose from 277 parts per million (ppm) (Joos and Spahni, 2008) to $411.53 \mathrm{ppm}$ on October, 2020 (National Oceanic \& Atmospheric Administration, 2021). It has been found that there is a reduction in anthropogenic air pollution after the intervention of nations reacting to the Covid-19 pandemic. Every $1 \mu \mathrm{g} / \mathrm{m} 3$ rise in long-term PM2.5 exposure will lead to an increased risk of Covid-19 mortality by $15 \%$ (Wu et al., 2020c). A different study conducted in Italy showed that the RNA of SARS-CoV-2 virus (Covid-19) was detected on coarse particulate matter (Setti et al., 2020). Air quality was found to cause 6.7 million deaths in 2019. In the same year, the State of Global Air (2020) revealed that 4.14 million deaths worldwide were caused by long-term exposure to PM2.5 pollution. It accounts for $62 \%$ of all death-induced air pollution. Over the last decade, the number of deaths caused by atmospheric PM2.5 has risen by nearly $23 \%$ worldwide.

A study conducted by Chakraborty and Maity (2020) found that the incidence of Covid-19 had improved environmental quality as emission was substantially reduced during the outbtreak. Examples of decreasing levels of pollution include greenhouse gas emissions, $\mathrm{NO}_{2}$, black carbon and water pollution (Chakraborty et al., 2020; Saadat et al., 2020; ZambranoMonserrate et al., 2020). Pozzer et al (2020) report that $15 \%$ of global Covid-19 deaths are caused by air pollution, of which 27 percent (13 to 46 percent) in East Asia, 19 percent ( 8 to 41 percent) in Europe, and 17 percent (6 to 39 percent) in North America. In many countries, 
decreased fossil fuel consumption has contributed to a dramatic reduction in air pollution (China, Italy, the US, and India). These conditions have contributed to the reduction of NO2 and $\mathrm{CO}_{2}$ emissions resulting from the cessation of industrial and automotive activities globally (Paital, 2020). $\mathrm{NO}_{2}$ is also decreasing by about 40 and 50 percent in major cities in India (Ahmedabad, Mumbai, and Pune) (Wright, 2020) and by about 40 percent in the United States (Paital, 2020).

In regions with relatively low levels of air emissions, such as Australia, the proportion of human-made air pollution associated with Covid-19 mortality is found to be just a few percent. Relatively higher fractions occur in areas of East Asia (35\%), Central Europe (25\%) and Eastern USA (25\%) while the average fraction of more than $25 \%$ is found in the Czech Republic, Poland, China, North Korea, Slovakia, Austria, Belarus, and Germany (Pozzer et al. 2020). Decreasing emissions is good news for people around the world because so far, no world event in the 20th century has been successful or has been able to significantly reduce emissions (Le Quéré et al., 2020). Almaty, Kazakhstan is one of the filthiest cities in the world (Carlsen et al., 2018) but during the lockdown the level of pollution in this area has shown a decreased concentration of PM2.5 by $21 \%$ with a spatial variance of $6-34 \%$ compared to the average on the same day in 2018-19. Next, there was also a drop of $49 \%$ in $\mathrm{CO}_{2}$ and $\mathrm{NO}_{2}$ concentrations (35\%). However, $\mathrm{O}_{3}$ was the reverse, as it revealed a rise of $15 \%$ compared to 17 days before the lockdown was implemented (Kerimray et al., 2020).

In countries such as Africa and West Asia, the amount of PM2.5 contributed by human activity can be smaller, but the high volume of Aeolian dust in those countries allows PM2.5 emissions to be a cofactor (Pozzer et al., 2020). So, it is possible that there is no significant change in terms of reducing the amount of air pollution in those countries. In the city of Salé, Morocco, there was a sharp decrease in $\mathrm{NO}_{2}$ concentrations from $5.6 \mu \mathrm{g} / \mathrm{m}^{3}$ to $0.2 \mu \mathrm{g} / \mathrm{m}^{3}$ and $\mathrm{PM} 10$ from $114.6 \mu \mathrm{g} / \mathrm{m}^{3}$ to $28.3 \mu \mathrm{g} / \mathrm{m}^{3}$. The concentration of $\mathrm{SO}_{2}$ decreased by $3.2 \mu \mathrm{g} / \mathrm{m}^{3}$ from 6.6 $\mu / \mathrm{m}^{3}$ to $3.3 \mu / \mathrm{m}^{3}$ (Otmani et al., 2020). The COVID-19 mobility restrictions enforced in Southeast Asia have resulted in a decrease in aerosol and ambient gas levels in the industrial, suburban, and rural areas, with equal level of reductions. For example, in Malaysia, concentrations of $\mathrm{PM} 10, \mathrm{PM} 2.5, \mathrm{NO}_{2}, \mathrm{SO}_{2}$ and $\mathrm{CO}_{2}$ decreased by $26-31 \%, 23-32 \%, 63-64 \%$, 9-20\% and 25-31\% respectively (Kanniah et al., 2020). In either case, according to McCloskey and Heymann (2020a), when this crisis finally decreases carbon emissions and the return of contaminants, the improvements that are taking place now will not have a lasting impact.

Apart from Covid-19, SARS (SARS-CoV-1) is also one of the epidemics associated with air pollution. As in China, moderate air pollution means that the risk of death from SARS is more than 80 percent higher than in less polluted regions, whereas the risk is twice as high in highly polluted areas (Cui, 2003). SARS-CoV-2 can be detected for up to 3 hours in aerosols (liquid and solid aerosols) that are similar to the SARS-CoV virus and influenza that have hit the world (Van Doremalen et al. 2020). The air quality crisis is not one which can be taken lightly because it is one of the primary risk factors causing multiple unnecessary deaths is PM2.5. This is how the air quality deteriorates primarily due to the fine particulate matter of $<2.5 \mu \mathrm{m}$ diameter (PM2.5) (Burnett et al., 2018). There is some other data indicating a decline in the amount of environmental pollution caused by Covid-19, which has been reduced to $30 \%$ in some Covid19 centers such as Wuhan, Italy, Spain, and the United States, etc (Muhammad et al., 2020). Studies have found that there is a substantial drop in air quality following the lockdowns (Dantas et al., 2020; Tobías et al., 2020). A study conducted by Wang et al (2020b) showed indication that the incidence of Covid-19 was substantially increased by PM2.5 in China. 


\section{Amid and Post Covid-19 Pandemic Affecting Sustainable Development Goals (SDGS)}

In their report, Nerini et al. (2020) found that Covid-19 had a negative impact on the achievement of 144 of the overall 169 Sustainable Development Goals (SDGs). However, it has been found that there are 66 targets with an approximate of $40 \%$ benefiting from the changes caused by the pandemic. At this point, we can conclude that the covid-19 pandemic not only has a negative effect, but it also has a positive effect. This is what is called as the butterfly effect of the Covid-19 pandemic on Sustainable Development Goals (SDGs). (Figure 2). There are six SDG Transformations that serve as the core organizers of SDG achievement namely Transformation (1) education, gender, and inequality; Transformation (2) health, wellbeing, and demographics; Transformation (3) decarbonization of energy and sustainable industries; Transformation (4) food, land, water and sustainable oceans; Transformation (5) sustainable cities and communities; and Transformation (6) the digital revolution for sustainable development (Sachs et al. 2019) (Figure 3).

\section{Global extreme poverty is getting worse amid a pandemic (SDG 1- End of poverty)}

Studies by Furceri et al. (2020) and Kikuchi et al. (2020) suggest that the Covid-19 pandemic may influence poverty and inequality. Before Covid-19 reached 19 countries around the world, SDG 1 aiming at ending poverty in all its forms was on track to end poverty by 2030. Predictions indicate that only $6 \%$ of the world's population will be living in extreme poverty by 2030 , but an additional 71 million people are estimated to be living in extreme poverty due to the impact of the Covid-19 (Lancet Public Health, 2020). During the pandemic, some workers were suspended even temporarily while waiting for the economy to recover or becoming unemployed (McCloskey et al. 2020b). Worst of all, as this pandemic is causing $75 \%$ of the 150 million people around the world to have no income protections, no unemployment insurance, and no sick leaves (International Labour Organization, 2020).

The worst-case scenario is when the global poverty situation in 2020 will approach the previous level of poverty in 2017. This situation means that the world's progress in eradicating extreme poverty will be reversed in three years (Mahler et al. 2020). Thus, it is presumable that the impact of Covid-19 can eliminate global progress in poverty reduction over the last 30 years (Sumner et al. 2020). In East Asia \& Pacific extreme poverty due to Covid-19 increased by $4.5 \%$, Europe \& Central Asia (0.9\%), Latin America \& Caribbean (2.7\%), Middle East \& North Africa (2.8\%), North America (0.1\%), South Asia (15.6\%) and Sub-Saharan Africa (22.6\%) (Mahler et al., 2020). The number of urban and rural poor in sub-Saharan Africa is projected to increase by $23 \%$, with 80 million people living in poverty. This is one of the most affected communities of the sub-Saharan Africa. Meanwhile the number of poor people in South Asia is projected to inflate by $15 \%$ which is 42 million (Laborde et al., 2020).

For the first time since 1990, Covid-19 could contribute to an increase in global poverty (Sumner et al., 2020). According to the November 2020 projections, the global socioeconomic crisis triggered by the COVID-19 pandemic could drive 142 million children into financially disadvantaged households by the end of 2020. The number of children living in poor households worldwide could exceed 725 million more than a year, with almost twothirds of these children living in sub-Saharan Africa and South Asia (UNICEF, 2020a). 


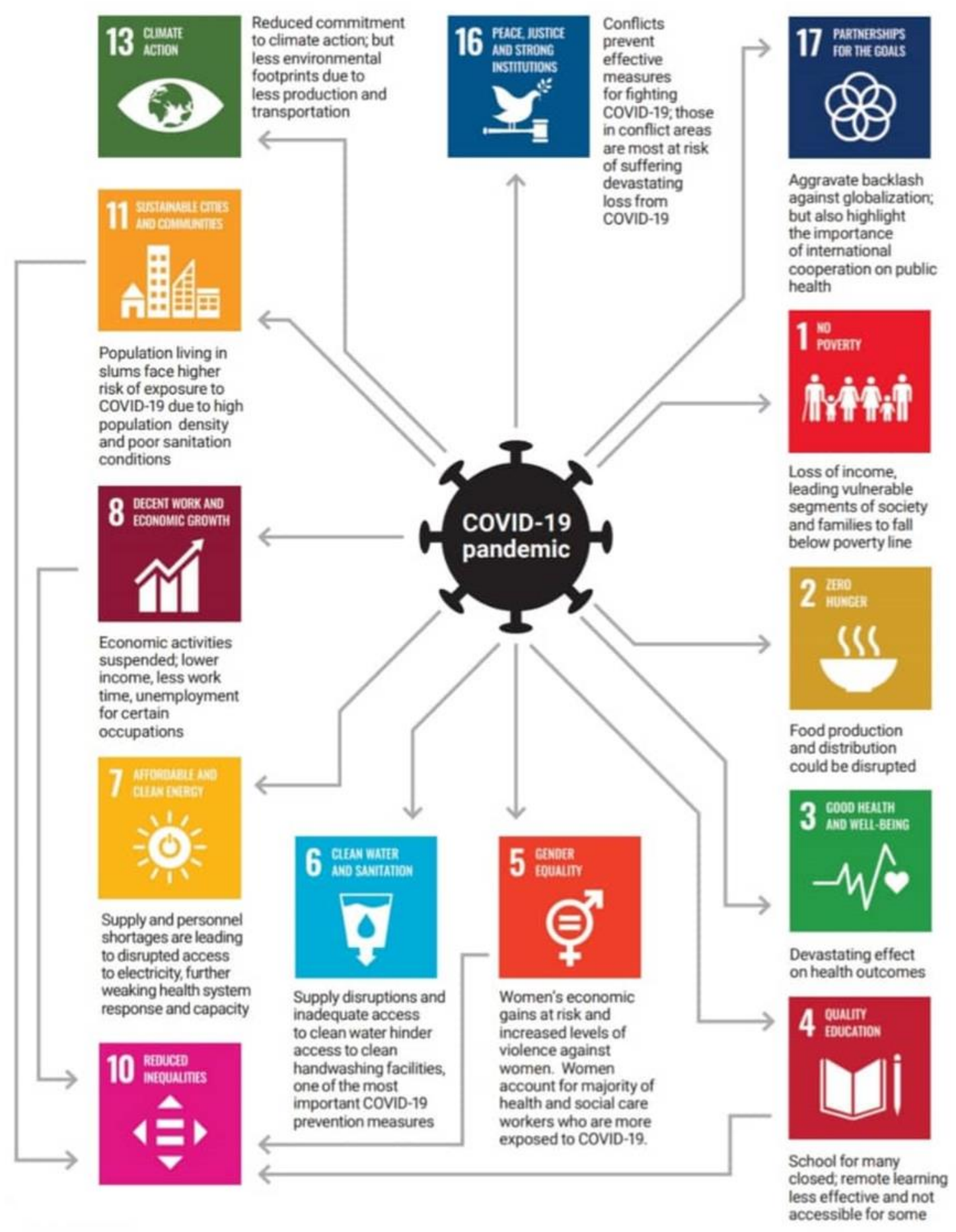

Figure 2. The Butterfly Effect \& Covid-19 (Source: United Nations, 2020b) 


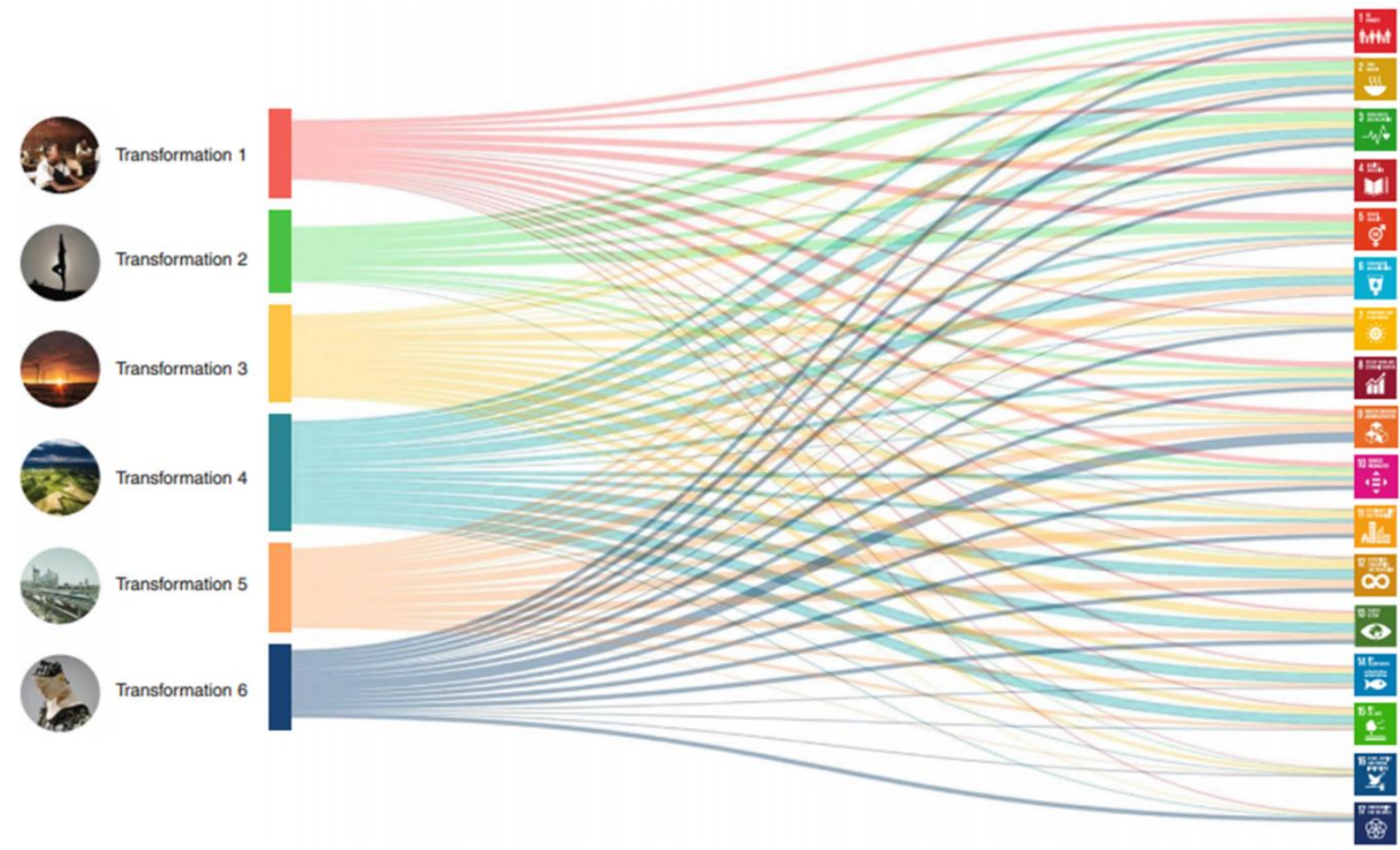

Figure 3. Contribution of each SDG Transformation towards the 17 SDGs (Source: Sachs et al. 2019).

\section{The rise in food insecurity induces hunger to occur during pandemics (SDG 2-Zero hunger)}

Sustainable Development Goal 2 aimed at eliminating hunger, achieving food security, and enhancing nutrition and promoting sustainable agriculture (General Assembly, 2015) has not yet been on the right track since Covid-19 struck (Lancet Public Health, 2020). Between 2014 and 2018, the population impacted by food insecurity has risen, but the global health emergency has now increased the burden on development, supply chain and household income, with the worst results (Lancet Public Health, 2020). By the end of 2020, there is a total of 138 million people suffering from hunger during the pandemic, and with the number of people exposed to food insecurity increasing from about 149 million to 270 million. Latest figures also suggest that 6,000 children will die every day for the next six months because of interrupted delivery of critical health and nutrition programmes and services due to this pandemic (World Food Programme, 2020). According to Udmale et al. (2020) developing countries such as Africa, Latin America, Oceania, and Asia are among the countries most vulnerable to food insecurity caused by the global Covid-19 pandemic. It is also due to the economic recession and increasing poverty, which reduce food supply and availability beyond 2020.

Reardon et al. (2020) revealed that the supply chain for essential goods, in particular food, had been disrupted or impaired when the transport industry was forced to suspend their operations due to the closures imposed. Apart from stunted production due to industrial closures, labour shortages caused by travel restrictions, morbidity and social distancing have affected food production stakeholders such as merchants, manufacturers, processors, and logistics (Schmidhuber et al., 2020). Therefore, the food supply chain is disrupted, and this would make it difficult to obtain food. This is also because according to Zurayk (2020) there are four aspects of food safety that need to be addressed during the Covid-19 pandemic, namely availability, access, use and stability. In addition, agricultural produce such as milk, 
vegetables, surplus livestock, and poultry had to be disposed of or destroyed in the United States and Canada (Weersink et al. 2020; Yaffe-Bellany and Corkery, 2020).

The global economic downturn triggered by Covid-19 in 2020 is predicted to result in a $24.8 \%$ decline in global food agricultural exports. Laborde et al. (2020) noted that the countries most affected by the decline in food agricultural exports were South East Asia (31.9\%), South Asia (30.7\%) and developing countries (30.5\%). In the meantime, developed countries are expected to experience a decrease of $23.8 \%$, South Africa of the Sahara (20.6\%) and Latin America (28.5\%). It is estimated that the impacted global food supply is attributed to currency exchange rates and a fall in the global Gross Domestic Product (GDP) (13\%) in the first half of 2020 due to export bans (Fernandes, 2020). According to Sova (2020), there are five major threats to global food security triggered by Covid-19. First and foremost, Covid-19 is a significant challenge to countries suffering from extreme poverty and insufficient healthcare facilities. Second, Covid-19 presents a major risk to countries which do not have large social security networks. Third, Covid-19 may prove to be extremely lethal to people suffering from starvation or chronic or acute malnutrition. Fourthly, Covid-19 will trigger instability of the food supply chain, food shortages and rising food prices. Finally, Covid-19 could cause the global economy to slow down or plunge into a recession that exacerbates extreme poverty and hunger.

\section{Exposure to air pollution $\left(\mathrm{NO}_{2}, \mathrm{O}_{3}, \mathrm{PM} 10, \mathrm{PM} 2.5 \& \mathrm{CO}_{2}\right.$ ) and mortality (SDG 3- Good Health and Well-Being)}

PM10, $\mathrm{NO}_{2}$ and $\mathrm{SO}_{2}$ are among the most common air contaminants in urban environments. Health conditions resulting from exposure to these chemicals include respiratory and cardiovascular disorders, blood pressure, and lung cancer (Koken et al. 2003; Le Tertre et al. 2002). Air pollution has become a serious predictor of the transmission and death rate of Covid-19 (Muhammad et al. 2020). Since SARS-CoV2 is known to be a respiratory virus that can infect the lungs, blood vessels, and many other parts of the body, exposure to air contaminants can further weaken the immune system of a person and make it susceptible to respiratory diseases and other infections. There are a wide variety of health problems that could be vulnerable to Covid-19 due to long-term exposure to air pollution, such as diabetes, cardiovascular disease, and chronic obstructive pulmonary disease (State of Global Air, 2020). A combination of respiratory and cardiovascular complications that may include myocardial infarction, heart failure, venous thromboembolism, and elevated biomarkers is associated with Covid-19 (Driggin, 2020). According to Miller (2020), these diseases are linked to a high level of air pollution.

Findings from several recent epidemiological studies indicate that elevated mortality is also associated with many air pollutants, including ozone $\left(\mathrm{O}_{3}\right)$ (Di et al. 2017), $\mathrm{NO}_{2}$ (Chiusolo et al. 2011) and $\mathrm{SO}_{2}$ (Kan et al. 2010). Increased mortality and morbidity are commonly associated with air contaminants such as $\leq 2.5 \mu \mathrm{m}$; PM25. (Di et al. 2017; Kioumourtzoglou et. al. 2016). A study by Faustini et al. (2014) indicated short-and long-term exposure to $\mathrm{NO}_{2}$ can increase fatality rates. According to $\mathrm{He}$ et al. (2020a and 2020b), $\mathrm{NO}_{2}$ is responsible for causing hyperbronchial responses, cell inflammation and respiratory complications. This scenario is reflected in the 1570155 death statistics reported by the European Centre for Disease Prevention and Control (2020b) on 10 December 2020.

People at or at high risk of contracting Covid-19 include those with diabetes, chronic respiratory disease, cardiovascular disease, high blood pressure, and cancer (Giannis et al. 2020; Fang et al. 2020; Zheng et al. 2020). Another research by Nikolich-Zugich et al. (2020) 
proved that older senior citizens were found to be more at risk for illness and had higher mortality rates than younger people. This is attributed to the clinical and immune response factors of the elderly. Lancet Public Health (2020) reports that Sustainable Development Goal 3 aimed at promoting a healthy life and well-being for everyone has been affected by the Covid-19 pandemic where about 70 countries across the world have ceased infant vaccination services, cancer screening health services, family planning, or non-Covid-19 infectious diseases coverage during this global health emergency.

In addition, the effects of Covid-19 on human health and well-being are likely to be also linked with mental stress and indirect psychiatric complications (Temsah et al., 2020). This claim is also supported by Bao et al. (2020) who argued that previous pandemics have taught people that pandemics can have a major psychological impact. Indirectly, Covid-19 can contribute to neuropsychiatric problems such as fear, anxiety, depression, panic attacks, psychomotor excitement, suicide, and decreased overall well-being (Brooks et al. 2020; Xiang et al. 2020). As a result, numerous studies have shown that the pandemic has also had a substantial psychological impact on the general population, patients, medical workers, children and older adults (Chen et al. 2020b; Yang et al. 2020; Li et al. 2020b). Residents in Wuhan, China were found to have experienced fear, isolation, panic, anxiety and depression during coronavirus outbreaks (Duan and Zhu, 2020; Xiang et al., 2020).

\section{Deteriorating educational quality and new norms in the education system (SDG 4- Quality Education)}

Sustainable Development Goal 4 aims to ensure sustainable and equal quality education and to foster lifelong learning opportunities for everyone (General Assembly, 2015) have also been affected by the Covid-19 crisis (Lancet Public Health, 2020). The entire curriculum, assessment and evaluation system has been interrupted by this pandemic, starting a new semester or term and if unavoidable, extending the academic year (Pujari, 2020). Projections say that more than $\mathbf{2 0 0}$ million children around the world will have to miss their schooling by 2030. A significant proportion of children around the world have lost their formal education since the crisis of COVID-19 that has hit the world (Lancet Public Health, 2020). It is estimated that 138 countries have closed schools worldwide, and many other countries have only enforced state or local closures. The closure of schools has impacted $80 \%$ of the world's children's education (Van Lancker and Parolin, 2020). Most worrying is the fact that underprivileged students are forced to continue their school sessions with lacking ICT facilities and lower educational resources (Di Pietro et al. 2020).

School closures due to the pandemic have also affected students emotionally or psychologically. In China for example, $53.8 \%$ of students are found to have a moderate to serious psychological crisis (Wang et al., 2020c). Approximately $24.9 \%$ of college students in China have been identified with anxiety because of the pandemic (Cao et al., 2020). Any form of public health crisis that strikes will undoubtedly have a great deal of psychological effects on college students. Psychological symptoms include anxiety, fear, and worry (Mei et al., 2011). In addition, this pandemic also impacts the development of higher education. These include the transition to online teaching and learning, the cancelation of physical events and programs, and the creation of a new 'normal' in higher education (Tesar, 2020). Online learning is the approach used to address higher education problems, but students and educators also have negative concerns about the efficacy of learning and engagement (Xiong et al. 2020). 
Owing to the lack of remote learning policies or the lack of facilities required to study at home, 463 million students worldwide have been found to have no access to schooling. At least $31 \%$ of students in primary and upper secondary schools are unreachable worldwide (UNICEF, $2020 \mathrm{~b})$. The number of pre-primary to upper secondary students potentially reached 68 million (50.37\%) in Eastern and Southern Africa and 67 million (49.63\%) unreached. While 59 million (52.51\%) in West and Central Africa could potentially surpass 54 million (47.49\%); the Middle East and North Africa (55 million, 52. 21\%; 37 million, $47.79 \%$ ); South Asia (244 million, 62.40\%; 147 million, 37.6\%); Eastern Europe and Central Asia (49 million, 66.22\%; 25 million, 33.78\%); East Asia and the Pacific (328 million, 79.41\%; 80 million, 20.59\%) and Latin America and the Caribbean (131 million, 90.97\%; 13 million, 9.03\%) (UNICEF, 2020b).

Globally, 3 out of 4 students with distance learning programmes that are unreachable come from rural areas and/or disadvantaged families. In rural areas, $77 \%$ are unreachable in lowincome countries, Lower-Middle Income (81\%) and Upper-Middle Income countries (70 \%). In low-income countries, $47 \%$ of those who are unavailable, while in Lower-Middle-Income and Upper-Middle-Income countries, they make up $74 \%$ to $86 \%$ of those who cannot be reached (UNICEF, 2020b).

\section{Gender-based violence (GBV) and gender equality have intensified in the lock-down period (SDG 5- Gender Equality)}

Sustainable Development Goal 5 aimed at fostering gender equality and empowering women and girls (General Assembly, 2015) came to an end when Covid-19 struck. However, before the epidemic reached the target of gender equality, the result was excellent, as fewer girls were forced to marry early and more women took up leadership roles. This is projected to result in an additional 13 million child marriages that would otherwise not have occurred between 2020 and 2030 (UNFPA, 2020). The UNFPA study (2020) indicates that Covid-19 is likely to lead to a one-third decrease in SDG 5 progress and that the total number of cases of gender-based violence will reach 15 million every three months of its closure. During the pandemic, domestic violence in some countries increased by $30 \%$ and the demand for unpaid jobs for women increased (Lancet Public Health, 2020). It also recorded that, during the quarantine era, gender-based violence escalated as women quarantined with their abusers and households faced financial difficulties (Capaldi et al., 2012).

According to CARE (2020), there are 9 possible gender implications, including services that help women and girls, which are often interrupted during public health emergencies; social norms place a heavy burden on women and girls, which can cause their physical and mental health to suffer and obstruct their access to education, livelihoods and other critical support; the needs of women and girls for safety themselves (CARE, 2020). Second, girls who are forced to drop out of school may experience significant repercussions on their educational, economic and health outcomes as a result of increased burdens on caregivers or economic pressures; access to sanitation and hygiene materials for women and girls would be limited during the global health crisis; female-headed households are more likely to have inadequate shelter and subject them to a higher chance of illnesses. Finally, the rations of food intake in the form of health emergencies that women generally consume last and least (CARE, 2020).

Mongey and Weinberg (2020) reported that there is a risk that employees will be affected differently during the lockdown. This is because the Covid-19 pandemic is projected to have an unbalanced negative impact on women and their employment opportunities (Surveillances, 2020). According to Boniol et al. (2019), the population of women in global health and social services is more than $70 \%$ of whom may be vulnerable to contamination 
with Covid-19 (CARE, 2020). Meanwhile, according to Jin et al. (2020), the number of men who died as a result of Covid-19 was 2.4 times higher compared to $70.3 \%$ and $29.7 \%$ respectively. While both men and women have been shown to have similar vulnerabilities, men have been found to be more likely to die (Jin et al. 2020). Preliminary studies have shown that men are at higher risk of disease and death with Covid-19 compared to women (Richardson et al., 2020).

Studies on women in the United States show that they want to delay or avoid pregnancy during the Covid 19 pandemic (Lindberg et al. 2020). Lindberg et al. (2020) also reported that one third of women in the United States reported delay or cancellation of contraceptive or sexual and reproductive health (SRH) treatment due to a Covid-19 pandemic. However, the situation is common among Black women (38\%) and Hispanic women (45\%) compared to White women (29 percent). The same is true of queer women (46\%) as they are commonly treated unequally compared to straight women (31\%). Inequality is also seen when lowincome women (36\%) face delays or are unable to receive contraceptive or SRH care due to pandemics compared to high-income women (31\%). This suggests the prevalence of ethnicity, sexual orientation, and household income inequalities in pre-and post-Covid-19 contraceptive or SRH treatment in the U.S.

Golden and Kim (2020) says that $11 \%$ of women now face unemployment compared to $4 \%$ of men. This is a direct consequence of the severe economic collapse of the pandemic. Industries that employ high female employees, such as hospitality, travel, food services and education, are among the sectors affected (Alon et al., 2020). This has been proven by several studies that have shown that in the United Kingdom (Hupkau and Petrongolo, 2020), in the United States (Cajner et al., 2020) the market prospects of women workers are more affected than men. Once again, a study conducted by Foucault and Galasso (2020) found that, during the outbreak in Austria, Canada, Germany, Italy, Poland and Sweden, the number of women workers who had quit work was higher than the number of men.

\section{Sustainable water and sanitation management for all is still a major global health issue (SDG 6- Clean Water and Sanitation)}

The impacts of Covid-19 on water quality include a significant decrease in water pollution in Venice, Italy because of the lockdown in the region. The evidence is that the rivers in Venice have been clearer than they have been since the lockdown was carried out (Saadat et al. 2020). Pollution on the coast, including the beaches of Acapulco (Mexico), Barcelona (Spain) and Salinas (Ecuador), is reported to have decreased significantly. This happened when the number of visitors declined and the water on the beach was clean again (ZambranoMonserrate et al., 2020). The quality of surface water at Vembanad Lake in India also increased significantly during the lockdown period in the country. This is because there is a 15.9\% decrease in suspended particulate matter (SPM) (Yunus et al., 2020). The Ganges River is a river that is heavily polluted in India but has improved to be cleaner in some areas (Mani, 2020). Although turbidity cannot be the only indicator of water quality, it has been used for the overall assessment of water quality (Luis et al., 2019).

Studies conducted by Wang and Su (2020) and Wang et al. (2019) have shown that pollution is directly proportional to the economic sector, where pollution will rise if economic growth often rises and pollution declines if economic slowdowns occur. It is therefore not surprising that air, water, noise and other pollution have been reduced since economic activity slowed down due to the implementation of mitigation measures for Covid-19. Sustainable Development Goal 6 to ensure availability and sustainable water and sanitation management 
for all is still a major global health issue (General Assembly, 2015). It has been found that some 2.2 billion people currently do not have access to clean drinking water, and the effects of the Covid-19 pandemic have further complicated the problem by cutting access to sanitation by billions (Lancet Public Health, 2020).

Approximately 818 million children worldwide are affected because of the lack of basic handwashing services available at school, and at least 355 million children have access to water while in school but do not have soap facilities. The worst situation is that there are about 462 million schools without water and hand-washing facilities, which puts these children at high risk of getting Covid-19. In addition, 3 out of 4 children in 60 high-risk countries faced health and humanitarian issues because of the Covid-19 pandemic that failed to provide primary hand-washing facilities in their schools early in the epidemic. Half of all children were also found to lack basic water facilities, as well as more than half of children without basic sanitation services (United Nations, 2020a). The report prepared by the United Nations (2020a) also indicated that 1 in 3 schools worldwide has limited or no drinking water facilities at all and 698 million children lack basic sanitation services.

\section{Demand for electricity is declining sharply globally (SDG 7- Affordable and Clean Energy)}

This Covid-19 pandemic has an impact on energy savings and may have an impact on the consumption of polluting fuels in power stations as demand has decreased (Lau et al., 2020). As a result of the reduction in commercial and industrial activities during the lockdown, it has been shown that electricity demand is declining by $20 \%$ on average every month, which is about $1.5 \%$ per year. In addition, demand for coal, gas and nuclear energy-based electricity also declined, with low-carbon electricity expected to grow to $40 \%$ by 2020 . Low-carbon electricity is projected to exceed $6 \%$ of coal by 2020 (IEA, 2020a). Global demand for electricity decreased by $2.5 \%$ in the first quarter (Q1) 2020. China, the first country to implement the lockdown in Q1 2020, recorded the world's largest decrease in demand at $6.5 \%$ (IEA, 2020b).

In addition to China, there has also been a decline in electricity demand in several other countries, such as Europe, Japan, Korea, and the United States. For these three countries, the decrease recorded was from 2.5\% in Q1 2019 to 4.5\% in Q1 2020. In the meantime, it has been recorded in France, India, Italy, Spain, the United Kingdom, and the United States in the northwest that, because of the complete lockdown, the demand for electricity per day in those countries has decreased by at least 15\% (IEA, 2020b). IEA (2020b) projects that, by 2020, with all fields of economic activity resuming, faster recovery would reduce energy demand by $2 \%$. With the widespread spread of Covid-19 in Africa, Latin America, and other parts of the developing world, and the second autumn wave in developed countries, a greater decrease of more than $5 \%$ is projected.

\section{Economic crisis and job losses leading to unemployment (SDG 8- Decent Work and Economic Growth)}

Preliminary projections predict that most major economies will lose at least $2.4 \%$ of their gross domestic product (GDP) by 2020 if the outbreak becomes a global pandemic (Statista Research Department, 2020). According to Outlook Market Mobility on Covid-19, the travel and tourism sector will see a decrease of about $42.1 \%$ by 2020 compared to 2019 . The expected revenue from this industry is US\$ 396.37 billion by 2020 , which is much lower than projected in early 2020 at about US\$ 712 billion (Lock, 2020a). The industry is expected to lose 75.2 million jobs worldwide by 2020 , with China expected to lose some 25.6 million jobs 
as the centre of the pandemic (Lock, 2020b). Projections for the first quarter (Q1) of 2020 saw oil demand fall by 750,000 barrels per day. In 2020 the quarterly turnover will fall to just 100,82 million barrels a day. Meanwhile, the analysis for the fourth quarter (Q4) revealed a decrease of 125,000 barrels per day (Sönnichsen, 2020).

The Covid-19 epidemic is associated with a threat to public health (Sohrabi et al. 2020) but at the same time has a serious impact on global economic development (Lai et al. 2020). The negative consequences of this epidemic can also be seen when speculation is triggered by a dramatic increase in economic growth (McKibbin and Fernando, 2020). Several researchers have shown that there has been an economic downturn during the pandemic (McKibbin et al. 2020; Fernandes 2020). For example, the stock market, which has dropped dramatically (Baker et al. 2020a) and many services and industrial industries are under pressure to cease operations (Del Rio-Chanona et al. 2020). Not only did Covid-19 lead the world into economic crisis, but previous epidemics (SARS, Spanish flu, etc.) also had a similar effect on the economy (Qiu et al. 2018). The Commission's forecast (2020) indicates the possibility that the EU has entered the deepest economic recess.

The effects of the economic slowdown of Covid-19 have an impact on socio-economic inequalities in the labour sector (Van Dorn et al. 2020). According to the World Economic Forum (2020a), the economic shock caused by the Covid-19 pandemic was three times worse than the 2008 financial crisis. Forecasts by the World Bank (2020) indicate that the global economy will decline by around $5.2 \%$ by 2020 . This is also the worst recession since the Second World War, with a limited proportion of the economy suffering a decline in per capita production since 1870 . Several studies have also shown that Covid-19 significantly disrupts labour supply and aggregate demand from most of the countries affected by the outbreak (Fetzer et al. 2020). Young and low-wage workers and self-employed workers in the United Kingdom were in the most economically unsafe place before the outbreak, let alone after the lockdown (Blundell et al. 2020).

Adam et al. (2020) mentioned that 16 percent of workers would risk more than 80 percent of their family income if they were unemployed. While another $20 \%$ would have lost between 60 and 80 percent of their earnings during the Covid 19 epidemic. In fact, unemployed people will also lead to stress problems in individuals who intend to commit suicide when they are no longer able to cope with extreme stress. For example, when Covid 19 hit, suicide rates were estimated to have risen by about $1 \%$ for every $1 \%$ of unemployment in Europe and the United States (World Economic Forum, 2020b).

Poor sanitation and crowded living areas (slums) increase transmission of the virus (SDG 11- Sustainable Cities and Communities)

Approximately 4 billion people live in urban areas worldwide and nearly 1 billion people live in slums worldwide (Baker et al. 2020b). In 61\% of the 59 developing countries, more than half of women between 15 and 49 years of age from 59 developing countries live in slums (Azcona et al. 2020). There are many factors that make people living in the slums one of the most at risk of exposure to Covid-19, such as the high population density in the slums that can accelerate transmission. It is estimated that about $60 \%$ of the population lives in slums where the slums are only around 6\% in Nairobi, Kenya. It appears that the population living in slums in Nairobi, Kenya, is at higher risk of exposure to Covid-19 due to high population density. Apart from Kenya, it has been found that almost $90 \%$ of transgender women living in overcrowded slums are also at high risk of contracting Covid-19 in Jakarta, Indonesia (Azcona et al. 2020). There are about 3394 crowded slums in Dhaka while in Dhaka. These areas are 
residential areas for people working as dayworkers, rickshaw-pullers, tea-stallers, CNG autorickshaw drivers, housewives, small business owners, mass-transport workers, street hawkers or garment workers (Hossain, 2020).

Poor sanitation conditions may also cause very high rates of transmission of agents, as overpopulation is also associated with deteriorating quality of life and sanitation (Baker et al. 2020b). Second, poor living conditions in slum settlements may worsen contagious behaviour. Poor living conditions, such as lack of water and sanitation, have thwarted efforts to slow down or eliminate Covid-19 infection. For example, in countries that have difficulty getting clean tap water, such as Kenya, the population is vulnerable to the spread of the virus (Baker et al. 2020b). It has been found that the residential area of Kibera, Slum, has only one toilet for 50 to 150 residents. Approximately 1.2 billion urban dwellers worldwide do not have access to hygiene and hand-washing facilities and 2.2 billion urban dwellers do not have access to clean, managed sanitation facilities (Azcona et al. 2020).

\section{National and sub-national elections rescheduled globally (SDG 16- Peace, justice, and strong institutions)}

One of the objectives of SDG 16 is to foster efficient, accountable, and inclusive institutions that are very important for sustainable development and most important for the government to provide services to its people. But governments around the world are under pressure to manage the impact and repercussions of the ongoing Covid-19 pandemic. As of 13 December 2020, it has been stated that at least 75 countries and territories around the world have decided to postpone national and sub-national elections and that at least 40 countries and territories have decided to postpone national elections and referendums due to the Covid-19 pandemic. Ninety-nine countries and territories have decided to hold national or sub-national elections, with at least 76 holding national elections or referendums. Finally, 48 countries and territories held elections that were originally delayed due to Covid-19, with at least 26 holding national elections or referendums (International IDEA, 2020) (Table 1).

Table 1. Postponed elections owing to Covid-19

\begin{tabular}{|c|c|c|c|}
\hline Continent & Type of election & $\begin{array}{l}\text { Original Date } \\
\text { and schedule }\end{array}$ & $\begin{array}{c}\text { Postponed } \\
\text { Date and } \\
\text { Schedule }\end{array}$ \\
\hline Africa & $\begin{array}{l}\text { a. Local by-elections for Metsimotlhabe } \\
\text { and Boseja South wards, Botswana. } \\
\text { b. Legislative elections, Chad. } \\
\text { c. Parliamentary election, Ethiopia. } \\
\text { d. Partial legislative election, Lékoni- } \\
\text { Lékori (Akiéni), Gabon. } \\
\text { e. National Assembly by-election, Niamina } \\
\text { West constituency, Gambia. } \\
\text { f. County Assembly and National } \\
\text { g. Midterm Senatorial elections and } \\
\text { national referendum, Liberia. } \\
\text { h. Municipal elections, Libya. } \\
\text { i. Senatorial by-elections in Bayelsa, Imo } \\
\text { and Plateau districts, Nigeria. }\end{array}$ & $\begin{array}{l}\text { a. May } 2020 \\
\text { b. } 13 \\
\text { December } \\
2020 \\
\text { c. } 29 \text { August } \\
2020 \\
\text { d. } 4 \text { and } 18 \\
\text { April } 2020 \\
\text { e. } 16 \text { April } \\
2020 \\
\text { f. April, } \\
\text { June-July } \\
2020 \\
\text { g. } 13 \text { October } \\
2020\end{array}$ & $\begin{array}{ll}\text { a. } & \text { Not Stated } \\
\text { b. } & \text { Not Stated } \\
\text { c. } & \text { Not Stated } \\
\text { d. } & \text { Not Stated } \\
\text { e. } & 7 \\
& \text { November } \\
& 2020 \\
\text { f. } & 15 \\
& \text { December } \\
& 2020 \\
\text { g. } & 8 \\
& \text { December } \\
& 2020 \\
\text { h. June } 2020\end{array}$ \\
\hline
\end{tabular}




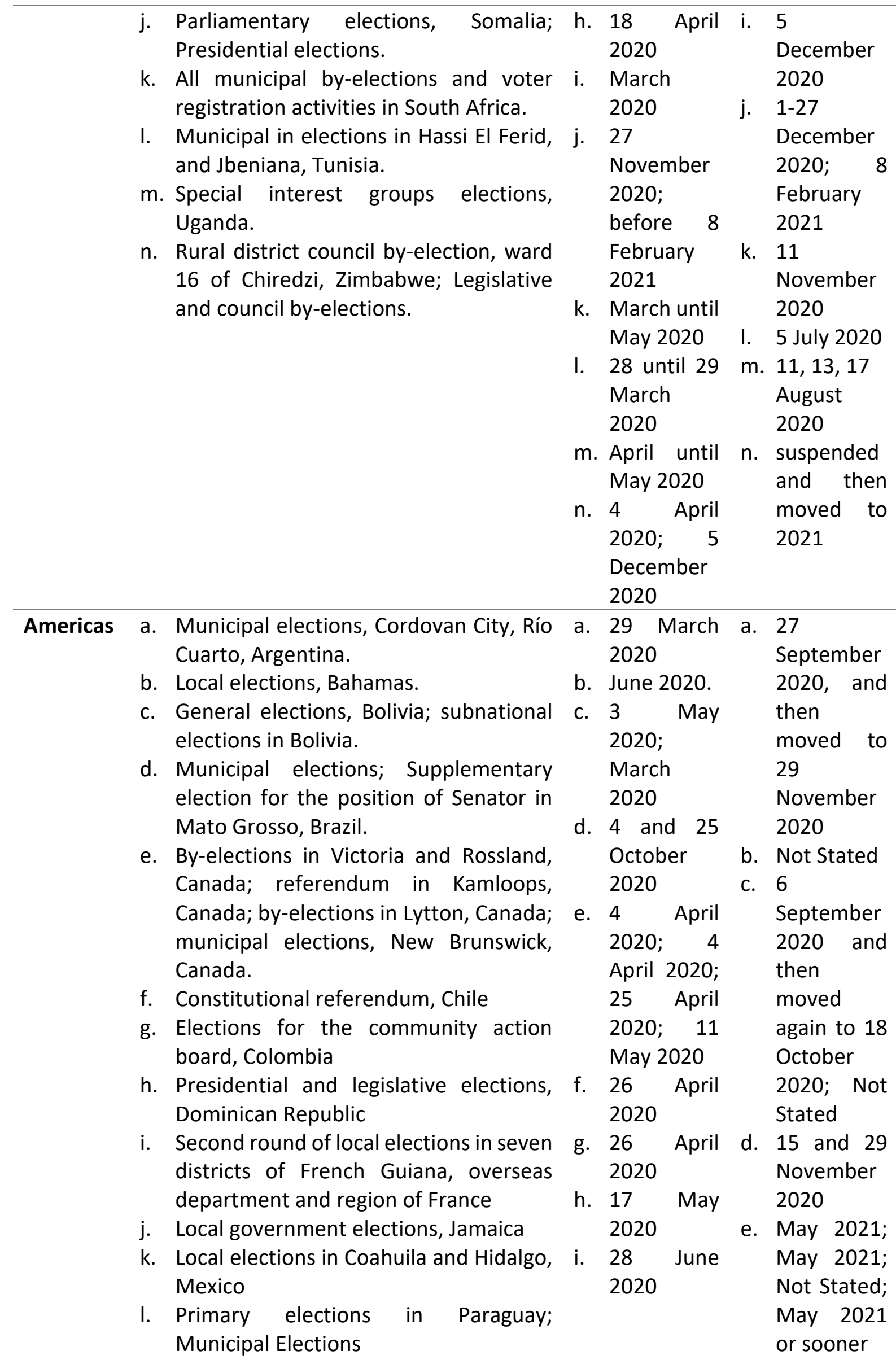




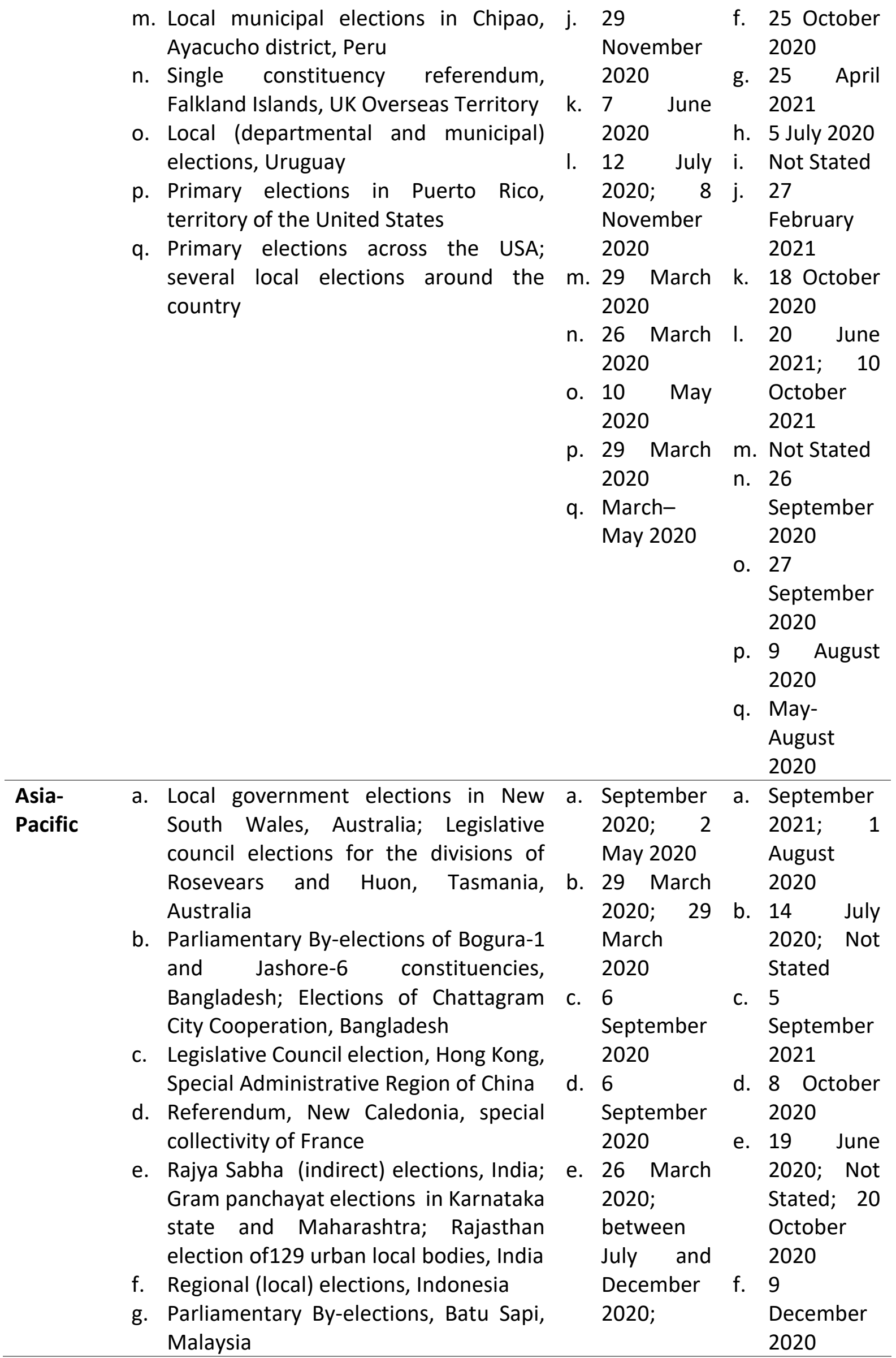




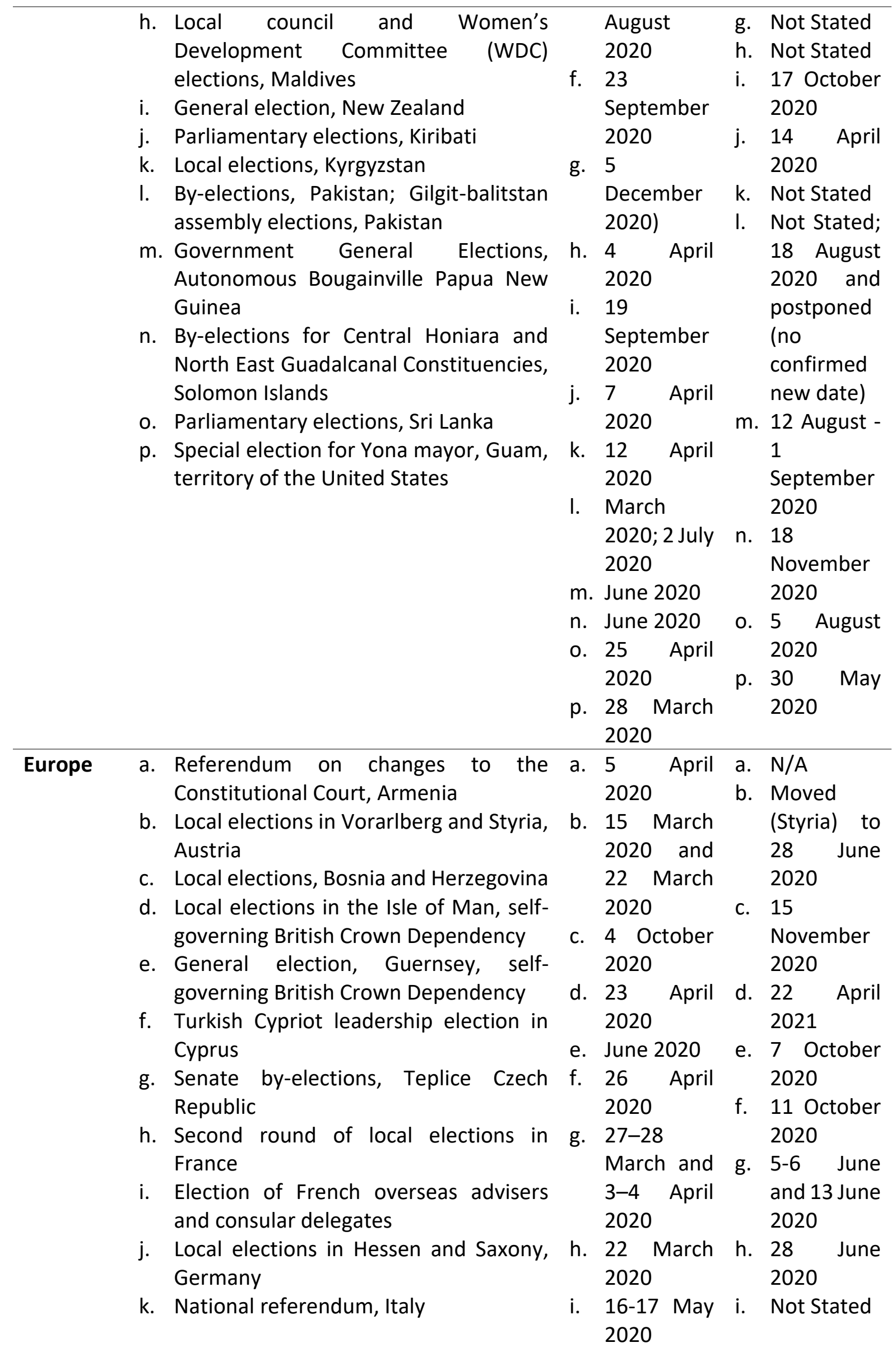


I. Extraordinary election for Mayor of the city of Podujeva, Kosovo

$\mathrm{m}$. Local snap elections for city council in Riga, Latvia

n. Local elections village Nucareni, district Telenesti and village Tirnova, district Donduseni, Moldova

o. Local elections in Tivat, Montenegro

p. Parliamentary elections in North Macedonia (originally scheduled for 12 April 2020) moved to 15 July 2020

q. Presidential elections, Poland

r. Local elections in Romania

s. Constitutional nation-wide referendum in Russia; The Central Election Commission of Russia took the decision covering about 94 electoral processes at local and regional levels

t. General elections in Serbia

u. Elections for local self-governing bodies, Slovakia

v. Regional elections in Euskadi/Basque and Galicia, Spain

w. Local referendum, Malung-Sälen, Sweden

x. Federal vote, Switzerland; several local (municipal) elections in the cantons of Neuchâtel, Ticino, and Luzern

y. Local elections in 118 English councils, the London Assembly and for seven English regional mayors as well as police and crime commissioners in England, UK; elections of police and crime commissioners in Wales, UK; local government by-elections in Kincorth/Nigg/Cove and Craigentinny/Duddingston, Scotland, UK; (Kincort/Nigg/Cove) and moved (Craigentinny/Duddinston)

z. Referendum on abortion, Gibraltar, UK Overseas Territory j.

AprilOctober 2020

k. 29 March 2020

I. 15 March 2020

m. 25 April 2020

n. 17 May 2020

o. 5 April 2020

p. 12 April 2020

q. 10 May 2020

r. June 2020

s. 22 April 2020; 3 April 2020

t. 26 April 2020

u. 4 April 2020

v. 5 April 2020

w. 17 May 2020

x. 17 2020;

April-June 2020

y. First week of May 2020; first week of May 2020; 14 and 21 May 2020; 14 and 21 May 2020

z. 19 March 2020 j. Moved (Hessen) to 14 March 2021

k. $20 / 21$ September 2020, (numerous regional and local elections moved to $20 / 21$ September 2020)

I. Not Stated m. 29 August 2020

n. 6

\section{September} 2020

o. 30 August 2020

p. 15 July 2020

q. 28 June 2020 and 12 July 2020

r. 27 September 2020

s. 1 July 2020 ; 5 April-23 June, covering about 94 electoral processes at local and regional levels

t. 21 June 2020

u. 3 October 2020 

v. 12 July 2020
w. 27
September 2020
x. 27
September 2020; Not Stated
y. moved to May 2021; Not Stated; 5
November
2020; 12
November 2020

z. Not Stated

\begin{tabular}{llllll}
\hline Middle & a. Second round of parliamentary & a. 17 April & a. & 11 \\
East & elections, Iran & & 2020 & & September \\
& b. Municipal council elections, Oman & b. Not Stated & 2020 \\
& c. Parliamentary elections, Syria & c. 13 April & b. Not Stated \\
& & & 2020 & c. 19 July \\
& & & & 2020
\end{tabular}

(Source: International IDEA, 2020).

\section{Conclusion}

The relationship between coronavirus pandemic 2019 (2019-nCoV) and air pollutants addressed in this review which are the $\mathrm{NO}_{2}, \mathrm{O}_{3}, \mathrm{PM} \mathrm{10}, \mathrm{PM} 2.5$ and $\mathrm{CO}_{2}$, may be positive or negative ones. From a positive perspective, the lock-down effect in almost every country in the world has been effective in reducing the release of pollutants into the atmosphere. As is known, these air pollutants may cause or trigger serious human health problems if they are present in excess in the atmosphere. Changes in human activities, such as closure of the economic and industrial sectors, the temporary closure of borders, the movement of control orders, social distances, lockdowns, and others, are among the contributors to the restoration of air quality. However, if a region has a severely polluted air pollution index, there is also a negative relation between Covid-19 and pollutants, then the transmission of coronavirus may occur more frequently, which in turn impacts human health and may cause death in the worst case. In addition, the Sustainable Development Goals (SDGs) have been facing numerous global issues since its inception, especially now that it must face the Covid-19 threat. The performance of the SDG was already on the right track in the previous year, but the emergence of this pandemic shattered the excellent progress and caused difficulties in achieving all 17 SDG goals. Perhaps what policymakers and societies around the world should do is revise the priorities of the SDG so that it is more applicable and can solve the issues that have now arisen. 
With reference to the earlier notions, it is clear that Covid-19 has high severity (negative) effect on the human health where the elderly suffer adverse, critical effects, and even mortality due to the pandemic. This age group is vulnerable and more susceptible to Covid19 infections which further weakens their immune systems, regardless of whether they have any underlying health problems. This scenario is further exacerbated by high levels of $\mathrm{NO}_{2}$, $\mathrm{O}_{3}, \mathrm{PM} 10, \mathrm{PM} 2.5$ and $\mathrm{CO}_{2}$ pollution in the surrounding air quality. This dilemma may be heightened by the length of exposure to these pollutants. Such information should be the defining elements to be considered in the development of policies on health and well-being aspects, with particular emphasis on vulnerable groups in society. Given the inevitable changing environment and the current urgent pandemic battle of Covid-19 the world is fighting, these key elements should be critically considered and addressed in developing emergency strategies for the vulnerable groups. The Covid-19 scenario also has an immediate positive effect on lowering the pollution levels where all efforts to achieve lower carbon emissions and other pollutant levels globally have not been significantly successful before the pandemic strikes. Although this positive impact is not long-lasting, literally the Covid-19 scenario should lead to the realization that our SDGs are highly achievable if societies work together as one. The methods and approaches adopted to combat Covid-19 outbreaks may differ from country to country, the outcome should be favorable, hence the phrase "think local, act global". The importance of international cooperation should also be emphasized. The United Nations may have identified its Butterfly Effect involving 13 of its SDGs in the case of the pandemic, but there are 10 SDGs that are highly impacted by Covid-19 requiring critical response. These are (SDG 1) No Poverty, (SDG 2) Zero Hunger, (SDG 3) Good Health and Wellbeing, (SDG 4) Quality Education, (SDG 5) Gender Equality, (SDG 6) Clean Water and Sanitation, (SDG 7) Affordable and Clean Energy, (SDG 8) Decent Work and Economic Growth, (SDG 11) Sustainable Cities and Communities, and (SDG 16) Peace, Justice and Strong Institutions. The emergency response and strategies, and eventually policies should prioritize these SDGs while addressing the defining elements discussed earlier. This pandemic has taught us an enormous lesson to be vigilant and to set our priorities right for the good of mankind, and in achieving sustainability.

\section{Acknowledgments}

The authors would like to thank School of Humanities, University Sains Malaysia for the facilities and providing a platform under HGG454: Selected Topics to encourage and motivate life-long learning and the opportunity to explore topics of interests.

\section{References}

Adam, S., Miller, H., \& Waters, T. (2020). Income Protection for the Self-employed and Employees during the Coronavirus Crisis. Institute for Fiscal Studies (IFS), Briefing Note no. BN277 (https://www. ifs. org. uk/publications/14786).

Adela, N., Nkengazong, L., Ambe, L. A., Ebogo, J. T., Mba, F. M., Goni, H. O., ... \& Oyono, J. L. E. (2020). Knowledge, attitudes, practices of/towards COVID 19 preventive measures and symptoms: A cross-sectional study during the exponential rise of the outbreak in Cameroon. PLoS neglected tropical diseases, 14(9), e0008700. DOI: https://doi.org/10.1371/journal.pntd.0008700.

Alon, T. M., Doepke, M., Olmstead-Rumsey, J., \& Tertilt, M. (2020). The impact of COVID-19 on gender equality (No. w26947). National Bureau of Economic Research. DOI: $10.3386 / w 26947$. 
Azcona, G., Bhatt, A., \& Ndugwa, R. (2020). COVID-19 exposes the harsh realities of gender inequality in slums: UN Women Data Hub. Retrieved from https://data.unwomen.org/features/ covid-19-exposes-harsh-realities-genderinequality-slums.

Baker, S. R., Bloom, N., Davis, S. J., Kost, K. J., Sammon, M. C., \& Viratyosin, T. (2020a). The unprecedented stock market impact of COVID-19 (No. w26945). National Bureau of Economic Research. DOI: 10.3386/w26945.

Baker, J., Cira, D., \& Lall, S. (2020). COVID-19 and the Urban Poor: Addressing Those in Slums. World Bank Group, 1.

Bao, Y., Sun, Y., Meng, S., Shi, J., \& Lu, L. (2020). 2019-nCoV epidemic: address mental health care to empower society. The Lancet, 395(10224), e37-e38.

DOI: https://doi.org/10.1016/S0140 6736(20)30309-3.

Boniol, M., Mclsaac, M., Xu, L., Wuliji, T., Diallo, K., \& Campbell, J. (2019). Gender equity in the health workforce: analysis of 104 countries (No. WHO/HIS/HWF/Gender/WP1/2019.1). World Health Organization.

Blundell, R., Dias, C. M., Joyce, R., \& Xu, X. (2020). COVID-19 and Inequalities. Fiscal Studies, 41(2), 291-319. DOI: https://doi.org/10.1111/1475-5890.12232.

Brooks, S. K., Webster, R. K., Smith, L. E., Woodland, L., Wessely, S., Greenberg, N., \& Rubin, G. J. (2020). The psychological impact of quarantine and how to reduce it: rapid review of the evidence. The Lancet. DOI: https://doi.org/10.1016/S0140-6736(20)30460-8.

Burnett, R., Chen, H., Szyszkowicz, M., Fann, N., Hubbell, B., Pope, C. A., ... \& Spadaro, J. V. (2018). Global estimates of mortality associated with long-term exposure to outdoor fine particulate matter. Proceedings of the National Academy of Sciences, 115(38), 9592-9597. DOI:https://doi.org/10.1073/pnas.1803222115.

Cajner, T., Crane, L. D., Decker, R. A., Grigsby, J., Hamins-Puertolas, A., Hurst, E., ... \& Yildirmaz, A. (2020). The US labor market during the beginning of the pandemic recession (No. w27159). National Bureau of Economic Research. DOI: 10.3386/w27159.

Cao, W., Fang, Z., Hou, G., Han, M., Xu, X., Dong, J., \& Zheng, J. (2020). The psychological impact of the COVID-19 epidemic on college students in China. Psychiatry research, 112934. DOI: https://doi.org/10.1016/j.psychres.2020.112934.

Capaldi, D. M., Knoble, N. B., Shortt, J. W., \& Kim, H. K. (2012). A systematic review of risk factors for intimate partner violence. Partner abuse, 3(2), 231-280.

DOI: 10.1891/1946-6560.3.2.231.

CARE. (2020). Gender implications of COVID-19 outbreaks in development and humanitarian settings. Retrieved from

https://insights.careinternational.org.uk/media/k2/attachments/CARE_Gender-i mplications-of-COVID-19_Full-Report_March-2020.pdf.

Carlsen, L., Bruggemann, R., \& Kenessov, B. (2018). Use of partial order in environmental pollution studies demonstrated by urban BTEX air pollution in 20 major cities worldwide. Science of The Total Environment, 610, 234-243. DOI:

https://doi.org/10.1016/j.scitotenv.2017.08.029.

Chakraborty, I., \& Maity, P. (2020). COVID-19 outbreak: Migration, effects on society, global environment and prevention. Science of the Total Environment, 138882. DOI: https://doi.org/10.1016/j.scitotenv.2020.138882.

Chen, N., Zhou, M., Dong, X., Qu, J., Gong, F., Han, Y., ... \& Zhang, L. (2020a). Epidemiological and clinical characteristics of 99 cases of 2019 novel coronavirus pneumonia in Wuhan, 
China: a descriptive study. The Lancet, 395(10223), 507-513. DOI: https://doi.org/10.1016/S0140-6736(20)30211-7.

Chen, Q., Liang, M., Li, Y., Guo, J., Fei, D., Wang, L., ... \& Zhang, Z. (2020). Mental health care for medical staff in China during the COVID-19 outbreak. The Lancet Psychiatry, 7(4), e15-e16. DOI: https://doi.org/10.1016/S2215-0366(20)30078-X.

Chiusolo, M., Cadum, E., Stafoggia, M., Galassi, C., Berti, G., Faustini, A., ... \& EpiAir Collaborative Group. (2011). Short-term effects of nitrogen dioxide on mortality and susceptibility factors in 10 Italian cities: the EpiAir study. Environmental health perspectives, 119(9), 1233-1238. DOI: https://doi.o rg/10.1289/ehp.1002904.

Cui, Y., Zhang, Z. F., Froines, J., Zhao, J., Wang, H., Yu, S. Z., \& Detels, R. (2003). Air pollution and casefatality of SARS in the People's Republic of China: an ecologic study. Environmental Health, 2(1), 1-5. DOI: https://doi.org/10.1186/1476-069X-2-15.

Dantas, G., Siciliano, B., França, B. B., da Silva, C. M., \& Arbilla, G. (2020). The impact of COVID19 partial lockdown on the air quality of the city of Rio de Janeiro, Brazil. Science of the Total Environment, 729, 139085.

DOI: https://doi.org/10.1016/j.scitotenv.2020.139085.

Del Rio-Chanona, R. M., Mealy, P., Pichler, A., Lafond, F., \& Farmer, D. (2020). Supply and demand shocks in the COVID-19 pandemic: An industry and occupation perspective. arXiv preprint arXiv:2004.06759. DOI: 10.1093/oxrep/graa033.

Di Pietro, G., Biagi, F., Costa, P., Karpinski, Z., \& Mazza, J. (2020). The likely impact of COVID19 on education: Reflections based on the existing literature and recent international datasets. JT Report, Ed. Luxembourg: Publications Office of the European Union. ISBN 978-92-76-19937-3. DOI: 10.2760/126686.

Di, Q., Wang, Y., Zanobetti, A., Wang, Y., Koutrakis, P., Choirat, C., ... \& Schwartz, J. D. (2017). Air pollution and mortality in the Medicare population. New England Journal of Medicine, 376(26), 2513-2522. DOI: 10.1056/NEJMoa1702747.

Donnelly, C. A., Ghani, A. C., Leung, G. M., Hedley, A. J., Fraser, C., Riley, S., ... \& Anderson, R. M. (2003). Epidemiological determinants of spread of causal agent of severe acute respiratory syndrome in Hong Kong. The Lancet, 361(9371), 1761-1766. DOI: https://doi.org/10.1016/S0140-6736( 03)13410-1.

Driggin, E., Madhavan, M. V., Bikdeli, B., Chuich, T., Laracy, J., Biondi-Zoccai, G., ... \& Parikh, S. A. (2020). Cardiovascular considerations for patients, health care workers, and health systems during the COVID-19 pandemic. Journal of the American College of Cardiology, 75(18), 2352-2371.

Duan, L., \& Zhu, G. (2020). Psychological interventions for people affected by the COVID-19 epidemic. The Lancet Psychiatry, 7(4), 300-302. DOI: https://doi.org/10.1016/S22150366(20)30073-0.

European Centre for Disease Prevention and Control. (2020a). COVID-19 situation update worldwide, as of 6 December 2020. Retrieved from https://www.ecdc.europa.eu/en/geo graphical-distribution 2019-ncov-cases.

European Centre for Disease Prevention and Control (ECDC). (2020b). COVID-19 pandemic: Situation update 10 December 2020. Retrieved from https://www.ecdc.europa.eu/en/covid-19-pandemic.

Fang, L., Karakiulakis, G., \& Roth, M. (2020). Are patients with hypertension and diabetes mellitus at increased risk for COVID-19 infection?. The Lancet. Respiratory Medicine, 8(4), e21. DOI: 10.1016/S2213-2600(20)30116-8. 
Faustini, A., Rapp, R., \& Forastiere, F. (2014). Nitrogen dioxide and mortality: review and meta-analysis of long-term studies. European Respiratory Journal, 44(3), 744-753. DOI: $10.1183 / 09031936.00114713$.

Fernandes, N. (2020). Economic effects of coronavirus outbreak (COVID-19) on the world economy. Available at SSRN 3557504. DOI: http://dx.doi.org/10.2139/ssrn.3557504.

Fetzer, T., Hensel, L., Hermle, J., \& Roth, C. (2020). Coronavirus perceptions and economic anxiety. Review of Economics and Statistics, 1-36. DOI: https://doi.org/10.1162/rest_a_00946.

Foucault, M., \& Galasso, V. (2020). Working After Covid-19: Cross-Country Evidence From Real-Time Survey Data1 (No. 9). Sciences Po.

Furceri, D., Loungani, P., Ostry, J. D., \& Pizzuto, P. (2020). COVID-19 will raise inequality if past pandemics are a guide. VoxEU column.

Gandhi, M., Yokoe, D. S., \& Havlir, D. V. (2020a). Asymptomatic Transmission, the Achilles' Heel of Current Strategies to Control Covid-19. The New England Journal of Medicine. 382:2158-2160. DOI: 10.1056/NEJMe2009758.

Gandhi, R. T., Lynch, J. B., \& del Rio, C. (2020b). Mild or moderate COVID-19. New England Journal of Medicine. 383:1757-1766. DOI: 10.1056/NEJMcp2009249.

General Assembly. (2015). Resolution adopted by the General Assembly on 19 September 2016. A/RES/71/1, 3 October 2016 (The New York Declaration).

Ghosh, A. K., Brindisi, M., Shahabi, D., Chapman, M. E., \& Mesecar, A. D. (2020). Drug Development and Medicinal Chemistry Efforts toward SARS-Coronavirus and Covid-19 Therapeutics. ChemMedChem. DOI: 10.1002/cmdc.202000223.

Giannis, D., Ziogas, I. A., \& Gianni, P. (2020). Coagulation disorders in coronavirus infected patients:COVID-19, SARS-CoV-1, MERS-CoV and lessons from the past. Journal of Clinical Virology, 104362. DOI: https://doi.org/10.1016/j.jcv.2020.104362.

Golden, L., \& Kim, J. (2020). Underemployment Just Isn't Working for U.S. Part-Time Workers. The Center for Law and Social Policy (CLASP). Retrieved from https://www.clasp.org/publications/report/bri ef/underemployment-just-isntworking-us-part-time-workers.

Gu, J., Han, B., \& Wang, J. (2020). COVID-19: gastrointestinal manifestations and potential fecal-oral transmission. Gastroenterology, 158(6), 1518-1519.

Guan, W. J., Ni, Z. Y., Hu, Y., Liang, W. H., Ou, C. Q., He, J. X., ... \& Zhong, N. S. (2020). Clinical characteristics of coronavirus disease 2019 in China. New England journal of medicine, 382(18), 1708-1720. DOI: 10.1056/NEJMoa2002032.

He, M. Z., Kinney, P. L., Li, T., Chen, C., Sun, Q., Ban, J., ... \& Kioumourtzoglou, M. A. (2020a). Short-and intermediate-term exposure to NO2 and mortality: a multi-county analysis in China. Environmental Pollution, 261, 114165.

DOI: https://doi.org/10.1016/j.envpol.2020.114165.

He, L., Zhang, S., Hu, J., Li, Z., Zheng, X., Cao, Y., ... \& Wu, Y. (2020b). On-road emission measurements of reactive nitrogen compounds from heavy-duty diesel trucks in China. Environmental Pollution, 114280.

DOI: https://doi.org/10.1016/j.envpol.2020.114280.

Hindson, J. (2020). COVID-19: faecal-oral transmission?. Nature Reviews Gastroenterology \& Hepatology, 17(5), 259-259. DOI: https://doi.org/10.1038/s41575-020-0295-7.

Hossain, M. D. I. (2020). COVID-19: Are we preparing the homeless and slum-dwellers? United News of Bangladesh (UNB). Retrieved from http://unb.com.bd/category/Special/covid19-are-we-preparing-the-homeless-and-slum-dwellers/48033. 
Huang, C., Wang, Y., Li, X., Ren, L., Zhao, J., Hu, Y., ... \& Cao, B. (2020). Clinical features of patients infected with 2019 novel coronavirus in Wuhan, China. The lancet, 395(10223), 497-506. DOI: https://doi.org/10.1016/S0140-6736(20)30183-5.

Hupkau, C., \& Petrongolo, B. (2020). COVID-19 and gender gaps: Latest evidence and lessons from the UK. VoxEU. org, 22.

IEA. (2020a). Power - The Covid-19 Crisis and Clean Energy Progress - Analysis. Retrieved from https://ww w.iea.org/reports/the-covid-19-crisis-and-clean-energy-progress/power.

IEA, I. (2020b). Electricity - Global Energy Review 2020 - Analysis. Retrieved from https://www.iea.org/re ports/global-energy-review-2020/electricity.

International IDEA. (2020). Global overview of COVID-19: Impact on elections. Retrieved from https://www.idea.int/news-media/multimedia-reports/global-overview-covid-19impact-election s.

International Labour Organization (ILO). (2020). Most of World Lacks Unemployment Insurance. Retrieved from https://www.ilo.org/global/about-theilo/newsroom/news/WCMS_007901/lang--en/index.h tm.

Jin, J. M., Bai, P., He, W., Wu, F., Liu, X. F., Han, D. M., ... \& Yang, J. K. (2020). Gender differences in patients with COVID-19: Focus on severity and mortality. Frontiers in Public Health, 8, 152. DOI: https://doi.org/10.3389/fpubh.2020.00152.

Joos, F., \& Spahni, R. (2008). Rates of change in natural and anthropogenic radiative forcing over the past 20,000 years. Proceedings of the National Academy of Sciences, 105(5), 1425-1430.

Jung, S., Kneer, J., \& Krüger, T. H. (2020). Mental health, sense of coherence, and interpersonal violence during the CoViD-19 pandemic lockdown in Germany. Journal of clinical medicine, 9(11), 3708. DOI: https://doi.org/10.3390/jcm9113708.

Kan, H., Wong, C. M., Vichit-Vadakan, N., \& Qian, Z. (2010). Short-term association between sulfur dioxide and daily mortality: The Public Health and Air Pollution in Asia (PAPA) study. Environmental research, 110(3), 258-264.

DOI: https://doi.org/10.1016/j.envres.2010.01.006.

Kanniah, K. D., Zaman, N. A. F. K., Kaskaoutis, D. G., \& Latif, M. T. (2020). COVID-19's impact on the atmospheric environment in the Southeast Asia region. Science of The Total Environment, 139658. DOI: https://doi.org/10.1016/j.scitotenv.2020.139658.

Kerimray, A., Baimatova, N., Ibragimova, O. P., Bukenov, B., Kenessov, B., Plotitsyn, P., \& Karaca, F. (2020). Assessing air quality changes in large cities during COVID-19 lockdowns: The impacts of traffic-free urban conditions in Almaty, Kazakhstan. Science of the Total Environment, 139179.

DOI: https://d oi.org/10.1016/j.scitotenv.2020.139179.

Khanh, N., Thai, P., Quach, H., Thi, N., Dinh, P., Duong, T....Anh, D. (2020). Transmission of SARS-CoV 2 During Long-Haul Flight. Emerging Infectious Diseases, 26(11), 26172624. DOI: https://dx.doi.org /10.3201/eid2611.203299.

Kikuchi, S., Kitao, S., \& Mikoshiba, M. (2020). Heterogeneous Vulnerability to the COVID-19 Crisis and Implications for Inequality in Japan. Research Institute of Economy, Trade and Industry (RIETI).

Kioumourtzoglou, M. A., Schwartz, J., James, P., Dominici, F., \& Zanobetti, A. (2016). PM2. 5 and mortality in 207 US cities: modification by temperature and city characteristics. Epidemiology (Cambridge, Mass.), 27(2), $221 . \quad$ DOI: 10.1097/EDE.0000000000000422. 
Koken, P. J., Piver, W. T., Ye, F., Elixhauser, A., Olsen, L. M., \& Portier, C. J. (2003). Temperature, air pollution, and hospitalization for cardiovascular diseases among elderly people in Denver. Environmental health perspectives, 111(10), 1312-1317. DOI: https://doi.org/10.1289/ ehp.5957.

Lai, C. C., Shih, T. P., Ko, W. C., Tang, H. J., \& Hsueh, P. R. (2020). Severe acute respiratory syndrome coronavirus 2 (SARS-CoV-2) and corona virus disease-2019 (COVID-19): the epidemic and the challenges. International journal of antimicrobial agents, 105924. DOI: https://doi.org/10.1016 /j.ijantimicag.2020.105924.

Lau, H., Khosrawipour, V., Kocbach, P., Mikolajczyk, A., Schubert, J., Bania, J., \& Khosrawipour, T. (2020). The positive impact of lockdown in Wuhan on containing the COVID-19 outbreak in China. Journal of travel medicine, 27(3), taaa037.

DOI: https://doi.org/10.1093/jtm/taaa037.

Laborde, D., Martin, W., \& Vos, R. (2020). Poverty and food insecurity could grow dramatically as COVID-19 spreads. International Food Policy Research Institute.

Lancet Public Health. (2020). Will the COVID-19 pandemic threaten the SDGs?. The Lancet. Public Health, 5(9), e460. DOI: 10.1016/S2468-2667(20)30189-4.

Le Tertre, A., Medina, S., Samoli, E., Forsberg, B., Michelozzi, P., Boumghar, A., ... \& Katsouyanni, K. (2002). Short-term effects of particulate air pollution on cardiovascular diseases in eight European cities. Journal of Epidemiology \& Community Health, 56(10), 773-779. DOI: http://dx.doi.or g/10.1136/jech.56.10.773.

Le Quéré, C., Jackson, R. B., Jones, M. W., Smith, A. J., Abernethy, S., Andrew, R. M., ... \& Peters, G. P. (2020). Temporary reduction in daily global CO 2 emissions during the COVID-19 forced confinement. Nature Climate Change, 1-7. DOI: https://doi.org/10.1038/s41558-020-0797-x.

$\mathrm{Li}, \mathrm{Q}$. (2020). An outbreak of NCIP (2019-nCoV) infection in China-wuhan, Hubei province, 2019- 2020. China CDC Weekly, 2(5), 79-80.

Li, Q., Guan, X., Wu, P., Wang, X., Zhou, L., Tong, Y., ... \& Feng, Z. (2020a). Early transmission dynamics in Wuhan, China, of novel coronavirus-infected pneumonia. New England Journal of Medicine. DOI: $\quad$ 10.1056/NEJMoa2001316.

Li, S. W., Wang, Y., Yang, Y. Y., Lei, X. M., \& Yang, Y. F. (2020b). Analysis of influencing factors of anxiety and emotional disorders in children and adolescents during home isolation during the epidemic of novel coronavirus pneumonia. Chinese Journal of Child Health, 28(3), 1-9.

Lindberg, L. D., VandeVusse, A., Mueller, J., \& Kirstein, M. (2020). Early impacts of the COVID19 pandemic: Findings from the 2020 Guttmacher Survey of Reproductive Health Experiences. New York, NY: Guttmacher Institute, 10(2020.31482).

Liu, H., Manzoor, A., Wang, C., Zhang, L., \& Manzoor, Z. (2020a). The COVID-19 outbreak and affected countries stock markets response. International Journal of Environmental Research and Public Health, 17(8), 2800.

DOI: https://doi.org/10.3390/ijerph17082800.

Liu, Z., Ciais, P., Deng, Z., Lei, R., Davis, S. J., Feng, S., ... \& Schellnhuber, H. J. (2020). Near-realtime monitoring of global CO 2 emissions reveals the effects of the COVID-19 pandemic. Nature communications, 11(1), 1-12.

Lock, S. (2020a). Forecasted change in revenue from the travel and tourism industry due to the coronavirus (COVID-19) pandemic worldwide from 2019 to 2020. Statista. Retrieved from https://www.statista.com/forecasts/1103426/covid-19-revenue-travel-tourismindustry-forecast. 
Lock, S. (2020b). COVID-19: job loss in travel and tourism sector worldwide 2020, by country. Statista. Retrieved from https://www.statista.com/statistics/1107475/coronavirustravel-tourism-employm ent-loss/.

Luis, K. M., Rheuban, J. E., Kavanaugh, M. T., Glover, D. M., Wei, J., Lee, Z., \& Doney, S. C. (2019). Capturing coastal water clarity variability with Landsat 8. Marine pollution bulletin, 145, 96-104. Doi: https://doi.org/10.1016/j.marpolbul.2019.04.078.

Mahler, D. G., Lakner, C., Aguilar, R. C., \& Wu, H. (2020). The impact of COVID-19 (Coronavirus) on global poverty: Why Sub-Saharan Africa might be the region hardest hit. World Bank Data Blog, 20 April 2020.

Majumder, M. S., Rivers, C., Lofgren, E., \& Fisman, D. (2014). Estimation of MERS-coronavirus reproductive number and case fatality rate for the spring 2014 Saudi Arabia outbreak: insights from publicly available data.PLoS currents, 6. Doi: 10.1371/currents.outbreaks.98d2f8f3382d84f390736cd5f5f e133c.

Mani, K. A. S. (2020). The lockdown cleaned the Ganga more than 'Namami Gange'ever did. The Wire. Retrieved from https://science.thewire.in/environment/ganga-riverlockdown-cleaner-nam ami-gange-sewage-treatment-ecological-flow/.

McCloskey, B., \& Heymann, D. L. (2020a). SARS to novel coronavirus-old lessons and new lessons. Epidemiology \& Infection, 148.

DOI: https://doi.org/10.1017/S0950268820000254.

McCloskey, B., Zumla, A., Ippolito, G., Blumberg, L., Arbon, P., Cicero, A., ... \& Borodina, M. (2020b). Mass gathering events and reducing further global spread of COVID-19: a political and public health dilemma. The Lancet, 395(10230), 1096-1099. DOI:https://doi.org/10.1016/S0140-6736(20)30681-4.

McKibbin, W., \& Fernando, R. (2020). The global macroeconomic impacts of COVID-19: Seven scenarios. Centre for Applied Macroeconomic Analysis, Crawford School of Public Policy, The Australian National University. DOI: http://dx.doi.org/10.2139/ssrn.3547729.

Mei, S. L., Yu, J. X., He, B. W., \& Li, J. Y. (2011). Psychological investigation of university students in a university in Jilin Province. Medicine and Society, 24(05), 84-86.

Miller, M. R. (2020). Oxidative stress and the cardiovascular effects of air pollution. Free Radical Biology and Medicine, 151, 69-87.

DOI: https://doi.org/10.1016/j.freeradbiomed.2020.01.004.

Mongey, S., \& Weinberg, A. (2020). Characteristics of workers in low work-from-home and high personal-proximity occupations. Becker Friedman Institute for Economic White Paper.

Muhammad, S., Long, X., \& Salman, M. (2020). COVID-19 pandemic and environmental pollution: a blessing in disguise?. Science of The Total Environment, 138820. DOI: https://doi.org/10.1016/j.scitotenv.2020.138820.

Narayan, P. K., Phan, D. H. B., \& Liu, G. (2020). COVID-19 lockdowns, stimulus packages, travel bans, and stock returns. Finance research letters, 101732-101732. DOI: https://doi.org/10.1016/j.frl.2020.1 01732.

National Oceanic \& Atmospheric Administration. (2021). Trends in atmospheric carbon dioxide. Retrieved from https://www.esrl.noaa.gov/gmd/ccgg/trends/global.html.

Nerini, F. F., Henrysson, M., Swain, A., \& Swain, R. B. (2020). Sustainable Development in the Wake of Covid-19. Research Square. DOI: https://doi.org/10.21203/rs.3.rs-63414/v1. 
Nikolich-Zugich, J., Knox, K. S., Rios, C. T., Natt, B., Bhattacharya, D., \& Fain, M. J. (2020). SARSCoV-2 and COVID-19 in older adults: what we may expect regarding pathogenesis, immune responses, and outcomes. Geroscience, 1-10.

DOI: https://doi.org/10.1007/s11357-020-00186-0.

Ong, S. W. X., Tan, Y. K., Chia, P. Y., Lee, T. H., Ng, O. T., Wong, M. S. Y., \& Marimuthu, K. (2020). Air, surface environmental, and personal protective equipment contamination by severe acute respiratory syndrome coronavirus 2 (SARS-CoV-2) from a symptomatic patient. Jama, 323(16), 1610-1612. DOI: 10.1001/jama.2020.3227.

Otmani, A., Benchrif, A., Tahri, M., Bounakhla, M., El Bouch, M., \& Krombi, M. H. (2020). Impact of Covid-19 lockdown on PM10, SO2 and NO2 concentrations in Salé City (Morocco). Science of The Total Environment, 139541. DOI: https://doi.org/10.1016/j.scitotenv.2020.139541.

Paital, B. (2020). Nurture to nature via COVID-19, a self-regenerating environmental strategy of environment in global context. Science of The Total Environment, 139088. DOI: https://doi.org/10 .1016/j.scitotenv.2020.139088.

Peters, G. P., Andrew, R. M., Canadell, J. G., Friedlingstein, P., Jackson, R. B., Korsbakken, J. I., ... \& Peregon, A. (2020). Carbon dioxide emissions continue to grow amidst slowly emerging climate policies. Nature Climate Change, 10(1), 3-6. DOI: https://doi.org/10.1038/s41558-019-0659-6.

Pozzer, A., Dominici, F., Haines, A., Witt, C., Münzel, T., \& Lelieveld, J. (2020). Regional and global contributions of air pollution to risk of death from COVID-19. Cardiovascular research, 116(14), 2247-2253. DOI: https://doi.org/10.1093/cvr/cvaa288.

Pujari, R. (2020). Impact of CORONA Virus on Indian Education Systems. Purakala with ISSN 0971-2143 is an UGC CARE Journal, 31(31), 252-254.

Qiu, W., Chu, C., Mao, A., \& Wu, J. (2018). The Impacts on Health, Society, and Economy of SARS and H7N9 Outbreaks in China: A Case Comparison Study. Journal of environmental and public health, 2018, 2710185-2710185.

DOI: https://doi.org/10.1155/2018/2710185.

Reardon, T., Mishra, A., Nuthalapati, C. S., Bellemare, M. F., \& Zilberman, D. (2020). Covid19 's disruption of india's transformed food supply chains. Economic and Political Weekly, 55(18), 18-22.

Richardson, S., Hirsch, J. S., Narasimhan, M., Crawford, J. M., McGinn, T., Davidson, K. W., ... \& Zanos, T. P. (2020). Presenting characteristics, comorbidities, and outcomes among 5700 patients hospitalized with COVID-19 in the New York City area. Jama. DOI: 10.1001/jama.2020.6775.

Rodríguez-Morales, A. J., MacGregor, K., Kanagarajah, S., Patel, D., \& Schlagenhauf, P. (2020). Going global-Travel and the 2019 novel coronavirus. Travel medicine and infectious disease, 33, 101578. DOI: 10.1016/j.tmaid.2020.101578.

Saadat, S., Rawtani, D., \& Hussain, C. M. (2020). Environmental perspective of COVID19. Science of The Total Environment, $138870 . \quad$ DOI: https://doi.org/10.1016/j.scitotenv.2020.138870.

Sachs, J. D., Schmidt-Traub, G., Mazzucato, M., Messner, D., Nakicenovic, N., \& Rockström, J. (2019). Six transformations to achieve the sustainable development goals. Nature Sustainability, 2(9), 805-814. DOI: https://doi.org/10.1038/s41893-019-0352-9.

Schmidhuber, J., Pound, J., \& Qiao, B. (2020). COVID-19: Channels of Transmission to Food and Agriculture. Food and Agriculture Organization of the United Nations Rome. DOI: https://doi.org/10.4060/ca8 430en 
Setti, L., Passarini, F., De Gennaro, G., Barbieri, P., Perrone, M. G., Borelli, M., ... \& Clemente, L. (2020). SARS-Cov-2RNA Found on Particulate Matter of Bergamo in Northern Italy: First Evidence. Environmental Research, 109754.

DOI: https://doi.org/10.1016/j.envres.2020.109754.

Simonovich, V. A., Burgos Pratx, L. D., Scibona, P., Beruto, M. V., Vallone, M. G., Vázquez, C., ... \& Gamarnik, A. V. (2020). A Randomized Trial of Convalescent Plasma in Covid-19 Severe Pneumonia. New England Journal of Medicine. DOI: 10.1056/NEJMoa2031304.

Sohrabi, C., Alsafi, Z., O'Neill, N., Khan, M., Kerwan, A., Al-Jabir, A., ... \& Agha, R. (2020). World Health Organization declares global emergency: A review of the 2019 novel coronavirus (COVID 19). International Journal of Surgery. DOI: https://doi.org/10.1016/j.ijsu.2020.02.034.

Sönnichsen, N. (2020). Projected global oil demand volume following impact of Covid-19 by quarter in 2020. Statista. Retrieved from https://www.statista.com/statistics/332291/global-oil-demand-outlook-followingcovid-19/.

Sova, C. (2020). COVID-19 and the 5 Major Threats it Poses to Global Food Security. World Food Program USA. Retrieved from https://www.wfpusa.org/articles/covid-19 and-global-food-security/

State of Global Air. (2020). The latest data on air quality and health where you live and around the globe. Retrieved from https://www.stateofglobalair.org/.

Statista Research Department. (2020). Impact of the coronavirus pandemic on the global economy - Statistics \& Facts. Retrieved from https://www.statista.com/topics/6139/covid-19-impact-on-the-global-economy/.

Sumner, A., Hoy, C., \& Ortiz-Juarez, E. (2020). Estimates of the Impact of COVID-19 on Global Poverty. UNU-WIDER, April, 800-9. DOI: https://doi.org/10.35188/UNUWIDER/2020/800-9.

Surveillances, V. (2020). The epidemiological characteristics of an outbreak of 2019 novel coronavirus diseases (COVID-19)-China, 2020. China CDC Weekly, 2(8), 113-122.

Temsah, M. H., Al-Sohime, F., Alamro, N., Al-Eyadhy, A., Al-Hasan, K., Jamal, A., ... \& Somily, A. M. (2020). The psychological impact of COVID-19 pandemic on health care workers in a MERS-CoV endemic country. Journal of Infection and Public Health. DOI: https://doi.org/10.1016/j.jiph.2020.05.021.

Tesar, M. (2020). Towards a post-Covid-19 'new normality?': Physical and social distancing, the move to online and higher education. Policy Futures in Education, 18(5), 556559. DOI: https://doi.org/10.1 177/1478210320935671.

Tobías, A., Carnerero, C., Reche, C., Massagué, J., Via, M., Minguillón, M. C., ... \& Querol, X. (2020). Changes in air quality during the lockdown in Barcelona (Spain) one month into the SARS-CoV-2 epidemic. Science of the Total Environment, 138540. DOI: https://doi.org/10.1016/j.scitotenv.202 0.138540.

Udmale, P., Pal, I., Szabo, S., Pramanik, M., \& Large, A. (2020). Global food security in the context of COVID-19: A scenario-based exploratory analysis. Progress in Disaster Science, 7, 100120. DOI: https://doi. org/10.1016/j.pdisas.2020.100120.

UNICEF. (2020a). Child poverty and COVID-19. Retrieved from https://data.unicef.org/topic/child-poverty/covid-19/.

UNICEF. (2020b). COVID-19 and School Closures: Are children able to continue learning. Retrieved from https://data.unicef.org/resources/remote-learning-reachabilityfactsheet/. 
UNFPA. (2020). Impact of the COVID-19 Pandemic on Family Planning and Ending Genderbased Violence, Female Genital Mutilation and Child Marriage. Retrieved from, https://www.unfpa.org/resour ces/impact-covid-19-pandemic-family-planning-andending-gender-based-violence-female-genital

United Nations. (2020a). Progress on drinking water, sanitation and hygiene in schools report - special focus on COVID-19: UN-Water. Retrieved from https://www.unwater.org/progress-on-drinking-water-sanitation-and-hygiene-inschools-report-special-focus-on-covid-19/

United Nations. (2020b). Shared Responsibility, Global Solidarity: responding to the socioeconomic impacts of Covid-19. Retrieved from https://unsdg.un.org/resources/sharedresponsibility-global-solidarity-responding-socio-economic-impacts-covid-19.

Van Dorn, A., Cooney, R. E., \& Sabin, M. L. (2020). COVID-19 exacerbating inequalities in the US. Lancet (London, England), 395(10232), 1243. DOI: 10.1016/S0140-6736(20)30893$\mathrm{X}$.

Van Doremalen, N., Bushmaker, T., Morris, D. H., Holbrook, M. G., Gamble, A., Williamson, B. N., ... \& Lloyd-Smith, J. O. (2020). Aerosol and surface stability of SARS-CoV-2 as compared with SARS-CoV-1. New England Journal of Medicine, 382(16), 1564-1567. DOI: 10.1056/NEJMc2004973.

Van Lancker, W., \& Parolin, Z. (2020). COVID-19, school closures, and child poverty: a social crisis in the making. The Lancet Public Health,5(5), e243-e244. DOI: https://doi.org/10.1016/S2468-2667(20)30 084-0

Wang, D., Hu, B., Hu, C., Zhu, F., Liu, X., Zhang, J., ... \& Peng, Z. (2020a). Clinical characteristics of 138 hospitalized patients with 2019 novel coronavirus-infected pneumonia in Wuhan, China. Jama, 323(11), 1061-1069. DOI: 10.1001/jama.2020.1585.

Wang, B., Liu, J., Fu, S., Xu, X., Li, L., Ma, Y., ... \& Luo, B. (2020b). An effect assessment of airborne particulate matter pollution on COVID-19: a multi-city study in China. MedRxiv. DOI: https://doi.org/10.1101/2020.04.09.20060137.

Wang, C., Pan, R., Wan, X., Tan, Y., Xu, L., Ho, C. S., \& Ho, R. C. (2020c). Immediate psychological responses and associated factors during the initial stage of the 2019 coronavirus disease (COVID-19) epidemic among the general population in China. International journal of environmental research and public health, 17(5), 1729. DOI: https://doi.org/10.3390/ijerph17051729.

Wang, Q., Su, M., Li, R., \& Ponce, P. (2019). The effects of energy prices, urbanization and economic growth on energy consumption per capita in 186 countries. Journal of cleaner production, 225, 1017-1032. DOI: https://doi.org/10.1016/j.jclepro.2019.04.008.

Wang, Q., \& Su, M. (2020). Drivers of decoupling economic growth from carbon emission-an empirical analysis of 192 countries using decoupling model and decomposition method. Environmental Impact Assessment Review, 81, 106356. DOI: https://doi.org/10.1016/j.eiar.2019.106356.

Weersink, A., von Massow, M., \& McDougall, B. (2020). Economic thoughts on the potential implications of COVID-19 on the Canadian dairy and poultry sectors. Canadian Journal of Agricultural Economics/revue Canadienne D'agroeconomie. DOI: https://doi.org/10.1111/cjag.12240.

Weiss, S. R., \& Leibowitz, J. L. (2011). Coronavirus pathogenesis. In Advances in virus research (Vol. 81, pp. 85-164). Academic Press. DOI: https://doi.org/10.1016/B978-012-385885-6.00009-2. 
World Bank. (2020). COVID-19 to Plunge Global Economy into Worst Recession since World War II. Retrieved from https://www.worldbank.org/en/news/pressrelease/2020/06/08/covid-19-to-plun ge-global-economy-into-worst-recession-sinceworld-war-ii.

World Economic Forum. (2020a). World Vs Virus podcast: An economist explains what COVID19 has done to the global economy. Rretrieved from https://www.weforum.org/agenda/2020/09/an-econom ist-explains-what-covid-19has-done-to-the-global-economy/.

World Economic Forum. (2020b). The COVID-19 lockdown will take its own toll on health, researchers warn. Retrieved from https://www.weforum.org/agenda/2020/04/howthe-covid-19-lockdown-wi Il-take-its-own-toll-on-health/.

World Food Programme (WFP). (2020). New report shows hunger is due to soar as coronavirus obliterates lives and livelihoods. Retrieved from https://www.wfp.org/news/newreport-shows-hunger-due-soar-coronavirus-obliterates-lives-and-livelihoods.

World Health Organization. (2020a). Timeline of WHO's response to COVID-19. Retrieved from https://www.who.int/emergencies/diseases/novel-coronavirus2019/interactive-timeline.

World Health Organization (WHO). (2020b). Coronavirus disease (COVID-19) pandemic. Retrieved from https://www.who.int/emergencies/diseases/novel-coronavirus-2019.

Wright, R. (2020). The world's largest coronavirus lockdown is having a dramatic impact on pollution in India. Retrieved from

https://edition.cnn.com/2020/03/31/asia/coronavirus-lockdown-impact-poll utionindia-intl-hnk/index.html.

Wu, J. T., Leung, K., \& Leung, G. M. (2020a). Nowcasting and forecasting the potential domestic and international spread of the 2019-nCoV outbreak originating in Wuhan, China: a modelling study. The Lancet, 395(10225), 689-697.

DOI: https://doi.org/10.1016/S0140-6736(20)30260-9.

Wu, Y. C., Chen, C. S., \& Chan, Y. J. (2020b). The outbreak of COVID-19: An overview. Journal of the Chinese Medical Association, 83(3), 217.

DOI: $10.1097 / J C M A .0000000000000270$.

Wu, X., Nethery, R. C., Sabath, B. M., Braun, D., \& Dominici, F. (2020c). Exposure to air pollution and COVID-19 mortality in the United States. medRxiv. DOI: https://doi.org/10.1101/2020.04.05.200 54502.

Wu, F., Zhao, S., Yu, B., Chen, Y. M., Wang, W., Song, Z. G., ... \& Zhang, Y. Z. (2020d). A new coronavirus associated with human respiratory disease in China. Nature, 579(7798), 265-269. DOI: https://d oi.org/10.1038/s41586-0202008-3.

Xiang, Y. T., Li, W., Zhang, Q., Jin, Y., Rao, W. W., Zeng, L. N., ... \& Hall, B. J. (2020). Timely research papers about COVID-19 in China. The Lancet, 395(10225), 684-685. DOI: https://doi.org/10.1016/ S0140 6736(20)30375-5.

Xiong, W., Mok, K. H., \& Jiang, J. (2020). Hong Kong university students' online learning experiences under the Covid-19 pandemic.

Yaffe-Bellany, D., \& Corkery, M. (2020). Dumped milk, smashed eggs, plowed vegetables: food waste of the pandemic. The New York Times.

Yang, Y., Li, W., Zhang, Q., Zhang, L., Cheung, T., \& Xiang, Y. T. (2020). Mental health services for older adults in China during the COVID-19 outbreak. The Lancet Psychiatry, 7(4), e19. DOI:https://doi.org/10.1016/S2215-0366(20)30079-1. 
Yeo, C., Kaushal, S., \& Yeo, D. (2020). Enteric involvement of coronaviruses: is faecal-oral transmission of SARS-CoV-2 possible? The lancet Gastroenterology \& hepatology, 5(4), 335-337. DOI: https://doi.o rg/10.1016/S2468-1253(20)30048-0.

Yunus, A. P., Masago, Y., \& Hijioka, Y. (2020). COVID-19 and surface water quality: Improved lake water quality during the lockdown. Science of The Total Environment, 139012. DOI: https://doi.org/10.101 6/j.scitotenv.2020.139012.

Zambrano-Monserrate, M. A., Ruano, M. A., \& Sanchez-Alcalde, L. (2020). Indirect effects of COVID-19 on the environment. Science of the Total Environment, 138813. DOI: https://doi.org/10.1016/j.sc itotenv.2020.138813.

Zheng, Y. Y., Ma, Y. T., Zhang, J. Y., \& Xie, X. (2020). COVID-19 and the cardiovascular system. Nature Reviews Cardiology, 17(5), 259-260. DOI: https://doi.org/10.1038/s41569-020-0360-5.

Zhu, N., Zhang, D., Wang, W., Li, X., Yang, B., Song, J., ... \& Niu, P. (2020). A novel coronavirus from patients with pneumonia in China, 2019. New England Journal of Medicine, 382:727-733 DOI: 10.1056/NEJMoa2001017.

Zurayk, R. (2020). Pandemic and Food Security. Journal of Agriculture, Food Systems, and Community Development, 9(3), 1-5. DOI: https://doi.org/10.5304/jafscd.2020.093.014. 